\title{
SUONIKYLÄN KOLTTASAAMELAINEN ITKUPERINNE 1900-LUVULLA
}

Tämän artikkelin tarkoituksena on luoda ensimmäinen kattava katsaus 1900-luvun kolttasaamelaiseen itkuvirsi- eli itkuperinteeseen, sen esittämistilanteisiin, siitä kertovaan kirjalliseen aineistoon ja tallennettuihin musiikkiesimerkkeihin. Pohdin ensin kolttasaamelaisen itkun laajempaa kulttuurista kontekstia ja esittelen tutkimukseni lähtökohdat. Seuraavaksi tarkastelen analyyttisesti suomalaisissa äänitearkistoissa olevia esimerkkejä kolttasaamelaisista itkusta ja niiden esitystilanteista. Tarkastelen myös muuta kolttasaamelaista musiikkiperinnettä, joka linkittyy itkuihin joko käsiteltyjen teemojen tai musiikin ja tekstin rakennepiirteiden kautta. Lopuksi pohdin 190o-luvun aineistojen roolia kolttasaamelaisen itkuperinteen vahvistamistyössä.

Kolttasaamelaisen musiikkiperinteen tarkastelun yleinen lähtökohta on perinteen tulkitseminen ensisijaisesti kolttasaamelaisena kulttuurina ottaen kuitenkin huomioon myös naapurikansoilta tulleet vaikutteet. Kolttasaamelainen kulttuuri kytkeytyi 190o-luvun alkupuoliskolla laajempaan, Luoteis-Venäjän kulttuurialueeseen, jossa lukuisat kansat olivat vuorovaikutuksessa toisensa kanssa. Kolttasaamelaisten naapureina asui useita saamelaisia väestöryhmiä, venäläisiä, karjalaisia, norjalaisia ja suomalaisia.

Eri kansoja yhtenäistävinä yleisinä tekijöinä toimivat venäjän kieli, kulttuuri, hallinto, kaupankäynti, koulutus ja ortodoksinen uskonto. Venäläinen vaikutus näkyy selvästi myös 1900-luvun alkupuolen kolttasaamelaisessa kielessä ja 
kulttuurissa. Merkittävä vaikutus oli myös karjalaisella kulttuurilla. Tästä tarjoaa aikalaiskommentin kansanmusiikintutkija Armas Launis (1884-1959), joka hämmästyi tunnistaessaan karjalaisen kulttuurin piirteitä kolttasaamelaisessa kulttuurissa Petsamon tutkimusmatkallaan vuonna 1922:

\footnotetext{
Tullessani Petsamon alueelle kolttalappalaisten pariin luulin nimestä päättäen tulevani kansanheimon luo, joka on samaa ulkonäöltään helposti tunnettavaa sukua kuin muutkin näiden seutujen paimentolaiselämää viettävät asujamet. Mutta lappalaisia en sieltä löytänytkään, huomasin joutuneeni karjalaisheimoisen kansan pariin. Mitä muuta ovatkaan kolttalappalaiset kuin karjalaisia ja eritoten vienankarjalaisten veljï -- (Launis 1922, 28.)
}

Kolttasaamelaisen itkuperinteen kontekstin ymmärtämisen kannalta onkin tärkeää huomioida sen yhteys erityisesti sen rinnakkaisperinteeseen, karjalaiseen itkuvirteen. Itkuvirret ovat erityisesti osa Luoteis-Venäjän ortodoksisten kansojen musiikkikulttuureja. Saamelaisista kansoista itkut tunnetaan kolttasaamelaisten ohella myös muilta Kuolan alueella asuneista saamelaisilta: akkalan-, kiltinän- ja turjansaamelaisilta. Läntisiltä luterilaisilta saamelaisilta, kuten pohjoissaamelaisilta, ei tunneta itkuja. (Honko 1963: 89; Jouste 2019: 151; 2017: 40; Stepanova, E. 2011: 129.) Tämä laajempi kulttuuriyhteys näkyy itkuperinteen ohella siinä, että esimerkiksi kolttasaamelaiset leu'ddit ja muutkin itäsaamelaiset kertovat laulut ovat esitystavan ja rakenteidensa puolesta paljon läheisempää sukua PohjoisVienan joikuperinteelle, pohjoisvenäläisille lauluperinteille ja karjalaisten runolaululle kuin Skandinavian ja Suomen saamelaisperinteille (ks. Jouste 2008).

Venäläisen ja karjalaisen kulttuurin vaikutus kolttasaamelaisessa musiikkikulttuurissa alkoi heikentyä, kun kolttasaamelaisten perinteiset asuinalueet jaettiin Venäjän, Norjan ja Suomen kesken. Vuoden 1920 Tarton rauhassa Neuvosto-Venäjän alueesta lohkaistiin Suomelle Petsamon alue, johon kuului kolme kolttasaamelaista siidaa Suõ'nn'jel 'Suonikylä', Paččjokk 'Paatsjoki' ja Peäccam 'Petsamo'. Suomalaisessa perinteentutkimuksessa heräsi mielenkiinto Petsamon aluetta ja erityisesti kolttasaamelaista kulttuuria kohtaan, ja tätä historiallista vaihetta kuvaavaa aineistoa tallennettiin runsaasti arkistoihin. Tältä ajalta ovat myös tärkeimmät itkutallenteet. Toinen maailmansota muutti kuitenkin tilanteen. Pohjoinen Suomi evakuoitiin Lapin sodan alta syksyllä 1944, ja myös kolttasaa- 
melaiset joutuivat jättämään kotiseutunsa. Petsamo luovutettiin Neuvostoliitolle osana Pariisin rauhansopimusta. Kolttasaamelaisten evakko kesti vuoteen 1949, jolloin heidät asutettiin Inarin Sevettijärvelle, Keväjärvelle ja Nellimiin. Neuvostoliitossa asuvat kolttasaamelaiset pakkosiirrettiin pois raja-alueilta. Kolttasaamelaisten asuinalueen halkovien rajojen ja toisen maailmansodan jälkeisen uudelleenasuttamisen vaikutus kolttasaamelaiseen kulttuuriin oli voimakas. Eri alueiden kolttasaamelaisten väliset yhteydet katkesivat. Samoin katkesi Suomen ja Norjan puolelle asutettujen kolttasaamelaisten kulttuuriyhteys karjalaiseen ja venäläiseen kulttuuriin, joiden merkitys juuri musiikkikulttuurissa oli huomattava. Nyt valtakulttuuriksi tuli suomalainen kulttuuri ja aiemmasta monikulttuurisesta kokonaisuudesta oli enää jäljellä sen läntinen osa, johon kuuluivat pohjois- ja inarinsaamelaiset sekä norjalaiset. (Jouste 2014: 361-362; Lehtola 2015: 109; Linkola \& Linkola 2000: 158-167; Mustonen \& Mustonen 2011: 29-52.)

\section{Kolttasaamelainen itkuperinne ja tutkimus}

Kolttasaamelaisessa yhteisössä itkeminen on ollut naisten perinnettä, ja itkuvirsiä esitetään joko yksin tai osana yhteisön kollektiivista surutyötä. Kolttasaamen nykykielen nimitys itkuperinteelle on virss ja itkujen esittämisestä käytetään verbiä virsseed. 190o-luvun alkupuolen lähteissä, kuten esimerkiksi ainoan itkuperinnettä Suonikylässä tallentaneen suomalaisen musiikintutkijan Armas Otto Väisäsen (1890-1969) vuoden 1926 kenttämuistiinpanoissa esiintyy termi reäkk merkitsemässä itkuvirttä (sKs KRA. A. O. Väisäsen kokoelma. Kotelo 6: Petsamo 1926). Myös Toivo Immanuel Itkosen (1891-1968) mukaan reäkkad-verbillä on erityisesti Suonikylän murteessa tavallisen itkemisen rinnalla myös merkitys "laulaa itkuvirttä" (Itkonen 1958: 428). Kolttasaamelaiselle itkurunolle tyypillisimpiä kielellisiä ja tyylillisiä piirteitä ovat kiitteleminen, runsas kiertoilmausten, deminutiivi ja omistusliitteiden, puhekieleen kuulumattomien lisätavujen ja lisävokaalien sekä toistorakenteiden käyttö. Nämä piirteet vastaavat karjalaisen itkun piirteitä (vrt. Stepanova, E. 2011: 133-135).

Karjalaista itkua käsittelevässä tutkimuksessa itkuperinne jaetaan tavallisesti neljään osaan: kuolin-, hää-, rekryytti- ja tilapääitkuihin (Honko 1963, 86-94; Konkka 1985, 9-12; vrt. Stepanova, E. 2011: 128; Tolvanen 2014: 3-4). Jaottelun 
kolme ensimmäistä osaa liittyvät rituaalisiin ja yhteisöllisiin tapahtumiin, neljäs on luonteeltaan ei-rituaalinen ja henkilökohtainen. Väisänen jakaa myös kolttasaamelaisen itkun samoihin rituaalisiin osiin, mutta hän ei mainitse lainkaan tilapääitkuja (sKS KRA. A. O. Väisäsen kokoelma. Kotelo 6: Petsamo 1926). Viimeaikaisessa tutkimuksessa itkuja on tarkasteltu edellisen jaottelun lisäksi myös muiden piirteiden kautta, ja itkut voidaan jaotella esimerkiksi erilaisten esityskontekstien mukaan (Silvonen \& Stepanova 2019: 205).

Tarkastelen tässä artikkelissa kolttasaamelaista itkua, itkutilanteita, musiikin rakenteita ja itkukielen piirteitä teemojen kautta, jotka kuvaavat itkujen tehtävää kolttasaamelaisessa kulttuurissa sekä itkurunojen sisältöä. Teemat ovat: 1) vainajan hyvästely, hautaaminen ja muistelu, 2) morsian hyvästelee vanhempansa, 3) sotaan lähtevän miehen hyvästely, 3) kaipuu menetetyille asuinpaikoille ja 5) kiitollisuuden osoittaminen itkulla. Tämä jaottelu noudattaa läheisesti aiemman itkututkimuksen jaottelua. Koska tässä tutkimuksessa läpi käyty kolttasaamelainen aineisto sisältää verrattain vähän tallenteita ja kontekstitietoa itkutilanteista, perinteisen jaottelun mallin mukainen aineiston käsittely olisi vaarassa jäädä hyvin suppeaksi.

Itkujen funktio, tekstien suruun ja menetykseen liittyvät sisällöt, itkurunon tyylipiirteet ja musiikin rakenteet erottavat itkuvirret muusta kolttasaamelaisesta perinteestä. Kiinnittämällä huomio näihin piirteisiin voidaan etsiä vastaavuuksia myös muusta kolttasaamelaisesta musiikkiaineistosta. Vertaileva tutkimus on tärkeää myös siksi, että arkistoluetteloiden perusteella varsinaisia itkuiksi nimettyjä tallenteita ovat vain kolme suonikyläläiseltä Näskk Moshnikoffilta (1893-1984) tallennettua itkua (sKS KRA. A 503/15-16; SKS KRA. L 277a.). Kolttasaamelaisen musiikkiperinteeseen liittyvän tutkimustyöni kuluessa (ks. esim. Jouste 2006; 2008; 2011; 2017) arkistoista on tullut esiin musiikkiaineistoa, joka musiikin rakennepiirteiden, tekstin sisällön tai esitystapansa puolesta rinnastuu itkuperinteeseen. Tästä materiaalista analysoin kolme esitystä Dä'rjj Jefremoffilta (Kper AK/o548, Kper AK/o864, Kper AK/o871) ja yhden U'lljan Fofanoffilta (Kper AK/0561).

Olen esitellyt itkua käsittelevää tutkimustani kolttasaamelaiselle yhteisölle julkisissa esityksissä vuodesta 2017 lähtien ja saanut tukea hypoteesille, että tallennetusta aineistosta on löydettävissä perinteenlaji, jonka voi rinnastaa esimerkiksi karjalaisiin tilapäisitkuihin. Kolttasaamelaisen perinteentuntijan ja henki- 
lökohtaisesti Näskk Moshnikoffin tunteneen Lati Feodoroffin kanssa käymieni keskustelujen perusteella kolttasaamelaiset itkut onkin mahdollista tunnistaa esitystavan, esittäjän ilmaisemien tunteiden ja tekstissä käsiteltyjen aiheiden perusteella (h2020).

Kolttasaamelaisten arkistoaineistojen tutkimuksen kohdalla ongelma on ollut, että 1900-luvun mittavien keräysten aikaan (ks. Jouste 2014: 102-103) ei tutkimuksessa ollut julkaistuna juurikaan tietoa kolttasaamelaisesta musiikkiperinteestä eikä esimerkiksi siihen liittyvistä perinteenlajeista tai alueellisista piirteistä. Tämä näkyy puutteellisuuksina arkistoluetteloissa ja esimerkiksi siinä, että valtaosa kaikista tallennetuista esimerkeistä on nimetty joiuiksi. Tätä pohjoissaamelaiseen perinteeseen liittyvää perinteenlajin nimeä käytettiin aiemmin kuvaamaan yleisesti saamelaista tapaa laulaa erottelematta eri saamelaisryhmiä tai saamen kieliä. Ensimmäiset aineistojen analyysiin perustuvat kuvaukset kolttasaamelaisesta musiikkiperinteestä julkaistiin vasta 1970-luvun lopulla, jolloin valtaosa 1900-luvun keräyksistä oli jo tehty (Häkämies 1978; Laitinen 1977; 1981). Uusi tutkimustieto ei siis ehtinyt vaikuttaa keräykseen tai luettelointiin. Kolttasaamelaisia itkuja on käsitelty tutkimuksessa sangen suppeasti, lähinnä vain viitaten perinteen olemassaoloon ja kuvaillen itkutilanteita (Hämäläinen 1938; Itkonen 1948; Jouste 2006; 2019; Leisiö 1978; Saastamoinen 2000; Storå 1971).

Tämä tutkimus kuuluu saamentutkimuksen ja musiikintutkimuksen aloihin. Menetelminä ovat arkistoaineistoihin perustuva etnografinen kuvaus sekä teksti- ja musiikkianalyysi. Yksi kolttasaamelaisen musiikin ja myös itkujen keskeisimmistä piirteistä on saman sävelmän kertaaminen koko esityksen ajan. Sävelmien metrinen rakenne ei useimmiten ole tiukan määrämittainen ja sävelmä ja rytmi mukautuvat jatkuvasti uusiin runosäkeisiin. Analysoin musiikillista variaatiota paradigmaattisen transkription avulla, jossa samat musiikilliset aiheet asettuvat allekkain ja rakennepiirteiden pysyvyys tai muutos on helppo havaita (ks. Niemi \& Jouste 2013: 182-197). Olen soveltanut myös jo aiemmassa kolttasaamelaisen musiikin tutkimuksessani fragmentaarisen säerakenteen mallia, jonka mukaan esityksessä sävelmän säkeitä voidaan kerrata joko kokonaisina tai niistä voidaan valita kerrattavaksi lyhyempiä aiheita, fragmentteja (ks. Jouste 2017, 75-78). Tekstin tarkastelussa nojaudun kielitieteilijä Mikko Korhosen (1983) esittelemään, Markus Juutisen ja Eino Koposen kanssa täydentämääni (Jouste et al. 2020) kolttasaamelaisen lauletun kielen erityispiirteiden malliin sekä sovel- 
lan Eila Stepanovan karjalaisen itkukielen tyylin analyysia (Stepanova, E. 2011: 133-135). Artikkelissa olevat nuotinnokset olen tehnyt itse. Koltansaamenkielisten tekstien transkriptiotyössä ja suomentamisessa olen tehnyt yhteistyötä kolttasaamen asiantuntijoiden, Elias Moshnikoffin, Seija Sivertsenin, Eino Koposen, Markus Juutisen ja Miika Lehtisen kanssa (Jouste et al. 2007). Vertaan ajoittain kolttasaamelaista itkua karjalaiseen itkuun, sillä kyseessä on sukulaisperinne ja sitä on sekä tallennettu että tutkittu runsaasti (Stepanova, A. 2012: 9-10). Koska karjalaisen itkun tutkimuksessa korostetaan sitä, että itkut edustavat lähtökohtaisesti keskustelua myös tuonpuoleisen kanssa, pohdin myös tätä piirrettä kolttasaamelaisen perinteen valossa (ks. esim. Honko 1974: 56-57; Stepanova, E. 2015: 270-271; Tolvanen 2014: 3).

\section{Kuolinitku: vainajan hyvästely, hautaaminen ja muistelu}

Kolttasaamelaisessa kulttuurissa ortodoksisella uskonnolla on ollut voimakas vaikutus jo vuosisatojen ajan, mikä näkyy esimerkiksi kuolemaan, hautaamiseen ja vainajan muisteluun liittyvissä toiminnoissa (Storå 1971: 245). Tässä artikkelissa käyttämäni Itkosen ja Väisäsen tallentamat tiedot Suonikylän kolttasaamelaisten hautajaistavoista ja niissä esiintyvistä itkutilanteista liittyvät 1900-luvun alkuvuosikymmeniin, jolloin käytännöt olivat oletettavasti pitkälti samankaltaisia kuin esimerkiksi karjalaisessa kulttuurissa (vrt. Stepanova, E. 2011: 136).

Kolttasaamelaisessa perinteessä laajin itkutilanteiden kokonaisuus liittyi ihmisen kuolemaan ja hautaamiseen. Ensimmäinen itkemistilanne oli hetki heti ihmisen kuoleman jälkeen. Kuolemantapauksen jälkeen avattiin tuvan ovi ja ikkuna, jotta vainajan sielu pääsisi vapaasti ulos huoneesta. Ikonin eteen sytytettiin tuohus, jonka edessä rukoiltiin. (Itkonen 1948 II: 355-356; Storå 1971: 210.) Väisäsen kirjoittamien tietojen mukaan tuolloin itkettiin, että "[Vainaja] ei tule elämään [enää elämäänsä]", "[k]iitetään hyvin hoitamisesta" ja kysytään: "Miten voin nyt elää?" (SKS KRA. A. O. Väisäsen kokoelma. Kotelo 6: Petsamo 1926). Seuraavaksi vainaja pestiin ja puettiin hautaamista varten kuolinpukuun. Vainaja oli tuvassa kolmen päivän ajan ennen hautaamista. Pidettiin myös huolta siitä, ettei vainajan hajua hengitetä, sillä sen uskottiin aiheuttavan eläville kuolemanvaaran. Ruumiinpesijöidenkin täytyi varoa vainajan hajua ja peittää tämän suu 
liinalla. Arkku tehtiin vainajalle vasta kuoleman jälkeen, ja vainajaa siirrettäessä arkkuun omaiset hyvästelivät vainajan itkien ja kumarrellen. (Itkonen 1948 II: 355-356; SKS KRA. A. O. Väisäsen kokoelma. Kotelo 6: Petsamo 1926; Storå 1971: 211.) Toinen kuolemantapauksen jälkeinen itkemistilanne liittyi siihen, kun vainaja siirrettiin pois kotoa. Kolmannen kerran itkettiin varsinaisissa hautajaisissa ja laskettaessa vainajaa hautaan, jolloin arkun kansi avattiin viimeisiä hyvästelyjä varten. (Itkonen 1948 II: 356; Storå 1971: 238.) Neljäs itkutilanne koostuu vainajan muistojuhlista. Näistä ensimmäinen pidettiin kolmen päivän päästä vainajan hautaamisesta. Tämän jälkeen oli suremisjakso, jonka aikana Suonikylässä rajoitettiin muun muassa työntekoa. Surujakson pituus saattoi vaihdella. Tavallisesti se kesti joko 40 päivän tai kuuden viikon ajan, jonka päättyessä pidettiin yksityinen muistojuhla. Muistojuhlia saattoi olla useampiakin, esimerkiksi tasan vuosi kuoleman jälkeen. Kuolemaan liittyi uskomus, että kuolleen henki lentää ensin kolmeksi päiväksi Jumalan luo ja sen jälkeen palaa maan päälle vieraillakseen kaikissa paikoissa, missä on elämänsä aikana käynyt. Tämä matka voi kestää kolmesta viikosta kolmeen vuoteen. Vasta tämän jälkeen vainajan uskottiin pääsevän paratiisiin tai joutuvan helvettiin. (Itkonen 1948 II: 357; Storå 1971: 245246.) Edellä kuvatusta johtuen itkuissa käydään dialogia myös tuonpuoleiseen siirtyneen vainajan kanssa, sillä hänen henkensä uskotaan edelleen kuulevan ja näkevän kaiken ympärillään tapahtuvan (Storå 1971: 217).

Vuonna 1938 Suonikylässä vieraillut Antti Hämäläinen sattui paikalle tunnetun I'llep Sverloffin hautajaisten aikaan. Hän kuvaa Koltta-Lappia sanoin ja kuvin -kirjassaan hautajaisia ja hautajaisiin liittyviä itkutilanteita sekä sitä, kuinka vainajan sukulainen Dä'rjj Jefremoff oli itkenyt vainajan vieressä: 
Aikuista kuollutta käy koko suku hautajaisiin saakka kerran päivässä hyvästelemässä ja kiittelemässä. - - Hyvästelijä ja kiittelijä osaansa esittäessään, varsinkin jos kysymyksessä on nainen, kiihoittaa samalla itseään itkemällä, vaikka kolttain itkijänaisilla onkin mielestäni suuri ero karjalaisiin verrattuna. - - Tietäjä Illepin ruumiin ääressä esim. hänen köyhä sukulaisensa Darja ääneen itkiessään jutteli seuraavaan tapaan: »Sie olit hyvä sukulainen! Annoit usein sajua, annoit leipää, annoit monesti jauhojakin.» Tällaisessa tilaisuudessa saatetaan helposti, kuten meilläkin, vainajan hyviä töitä, - - vahvasti liioitellakin. Samassa Darja lueteltuaan pitkän rivin vainajan häntä kohtaan osoittamia hyviä töitä esittää - vetoomuksen läsnäolijoihin: »Kuinkas minun nyt käy? Löytyyköhän muita yhtä hyviä sukulaisia!» Muut itkijänaiset - - kulkevat läpi koko kylän ja esittävät saman näytelmän. Hyvästellessään ja kiitelleessään kuollutta samalla hypistellään sormin vainajan eri ruumiinosia. - - Ruumiille osoitetaan muutenkin suurta kunnioitusta. Aikuisen kuoltua ei esim. suuressa Suonikylässä tee kukaan työtä, ennen kuin vainaja on kätketty maan poveen. Pikkulapsenkin kuolema saa aikaan sen, että kaikenlainen ilonpito ja huvittelu koko kylässä lakkaa. Tanssit, joihin koltat ovat niin mielistyneet, ja »sierrat» (leikit) lopetetaan heti tyystin. (Hämäläinen 1938: 69-70.)

Seuraavasssa tarkastelen esimerkkiä kolttasaamelaisesta kuolinitkusta. Kyseessä on Näskk Mosnikoffin esittämä itku, jonka Väisänen tallensi Helsingissä vuonna 1936 (sKS KRA. L 277a.). Kyseessä on vuoropuhelu surijan ja vainajan välillä, eli itkijä esittää sekä surijan että vainajan vuorosanoja (vrt. Stepanova, E. 2011: 138). 
Tekstiesimerkki 1. sKs KRA. L 277a. Tekstin transkriptio ja suomenkielinen käännös: Elias Mosnikoff, Seija Sivertsen, Markus Juutinen ja Marko Jouste.

Ij kuâđđ-a-jam ni tuu g-â'lğğge, piârr-a-gaž-gaž-ža,

ij kuâđđ-a-jam tuu nijdd-a piârr-a-gaž-ža,

tõt kuâđđ-a-ji, tuu nuõrr-a g-ââggaž jeäl-e-̌̌keânna-na.

Ij ve't tå'ľk le'žže še vuäinn-a-maž,

mõõn-a le'žžep vuäinn-a-maž.

Â mat le'žžep jeä'l-e-škue'tted-ed-e

tuu pue'rr-e-vuõđâst-a

di tuu lokku vaajt-ad-ed-a.

De spä'sseb-e, spä'sseb ruåđaž-a peâmm-a-mast-a da ruõkk-a-mast-a tiu'dd-a šõõdd-jâ-laža-ža.

Â mat le'žžep jeä'l-e-škue'tted, tuu jeäll vuõi-'n-e-ǩkeânnai.

Jeä'ped le'žže kuullâd-ed-ed mâi'd-e le'žžep vuäinnam

Â mat ve't ton-e le'žžep poor-a-škue'tted-ed â mat le'žžep vuei'teškue'tted-ed.

Spä'sseb-e, spä'sseb-e šuurid spä'sseb-i

di tä'st tän-a g-ââ'lmest de tun-a g-âlmma.
Surija:

Ei jäänyt edes sinun poikaa perheeseen-seen,

Ei jäänyt sinun tyttöä perheeseen.

Se jäi, sinun nuori ikä(sesi), elämättä.

Eipä vain liene myös nähnyt,

mitä lienemme nähneet.

Miten alkaisimme elää

sinun hyvyydestä

ja sinun lukuun vaihtaa

Vainaja:

Niin kiitos, kiitos sukulaiset hoivaamisesta

ja hautaamisesta täyteen kasvattajaiseni

Surija:

Niin kuin lienemme alkamassa elämään,

sinun elämää näkemättä

Ette liene kuulleet

mitä lienemme nähneet.

Kuten sinä, lienemme alkamaan syödä.

Kaipa lienemme alkamaan jaksaa.

Kiitos, kiitos, suuret kiitokset

ja tästä tämänpuoleisesta niin tuonpuoleiseen. 
Itkun teksti jakautuu neljään osaan. Alussa surija kuvaa, kuinka vainajan nuori elämä jäi elämättä, ja kysyy, kuinka surijat voivat nyt jatkaa elämäänsä. Vainaja kiittää sukulaisiaan ja "täyteen vartaloon kasvattajaansa" eli isäänsä siitä, kuinka nämä huolehtivat myös hautaamisesta. Seuraavaksi surija ihmettelee, kuinka voi jatkaa taas elämää. Lopuksi surija lähettää vielä kiitokset tämänpuoleisesta maailmasta tuonpuoleiseen käyttäen kielikuvaa Spä'sseb tä'st tän- $a$ âa'lmest de tuna-âlmma 'Kiitos tästä tämänilmaisesta niin tuonilmaiseen'. Tämä vastaa karjalan kielen ilmaisuja tämäilma eli maanpäällinen elämä, tämänpuolinen ja tuoilma eli kuolemanjälkeinen elämä, tuonpuoleinen (ks. Itkonen 1958: 622; Karjalan kielen sanakirjan hakusanaluettelo; Stepanova, A. 2012: 74-75). Erityistä on, että tekstissä ei kerrota vainajan nimeä. Muutakaan tekstin sisältöä ei liitetä konkreettisesti mihinkään tiettyyn aikaan tai tapahtumaan, kuten esimerkiksi ihmisistä kertovissa leu'ddeissa on tapana. Vastaavat piirteet tunnetaan karjalaisista itkuista, joissa ei viitata suoraan itkun kohteisiin (vrt. Stepanova, E. 2011: 138; 2015: 263). Palaan runotekstin piirteisiin tarkemmin varsinaisessa runon tyylin ja kielen analyysissa artikkelin lopulla.

Olen nuotintanut Näskk Moshnikoffin esittämän kuolinitkun sävelmän puolisävelaskeleen tarkkuudella, jakanut paradigmaattisen analyysin avulla esityksen melodia-aiheet neljään tyyppiin $(\mathrm{a}, \mathrm{b}, \mathrm{c}, \mathrm{d})$ ja kirjoittanut melodian riveille siten, että samankaltaiset melodia-aiheet asettuvat allekkain (Nuottiesimerkki 1). Analyysissa käytetty termi sävelaste kuvaa aina sävelen sävelkorkeutta suhteessa melodian päättävään säveleen. (ks. Niemi \& Jouste 2013: 182-197). 


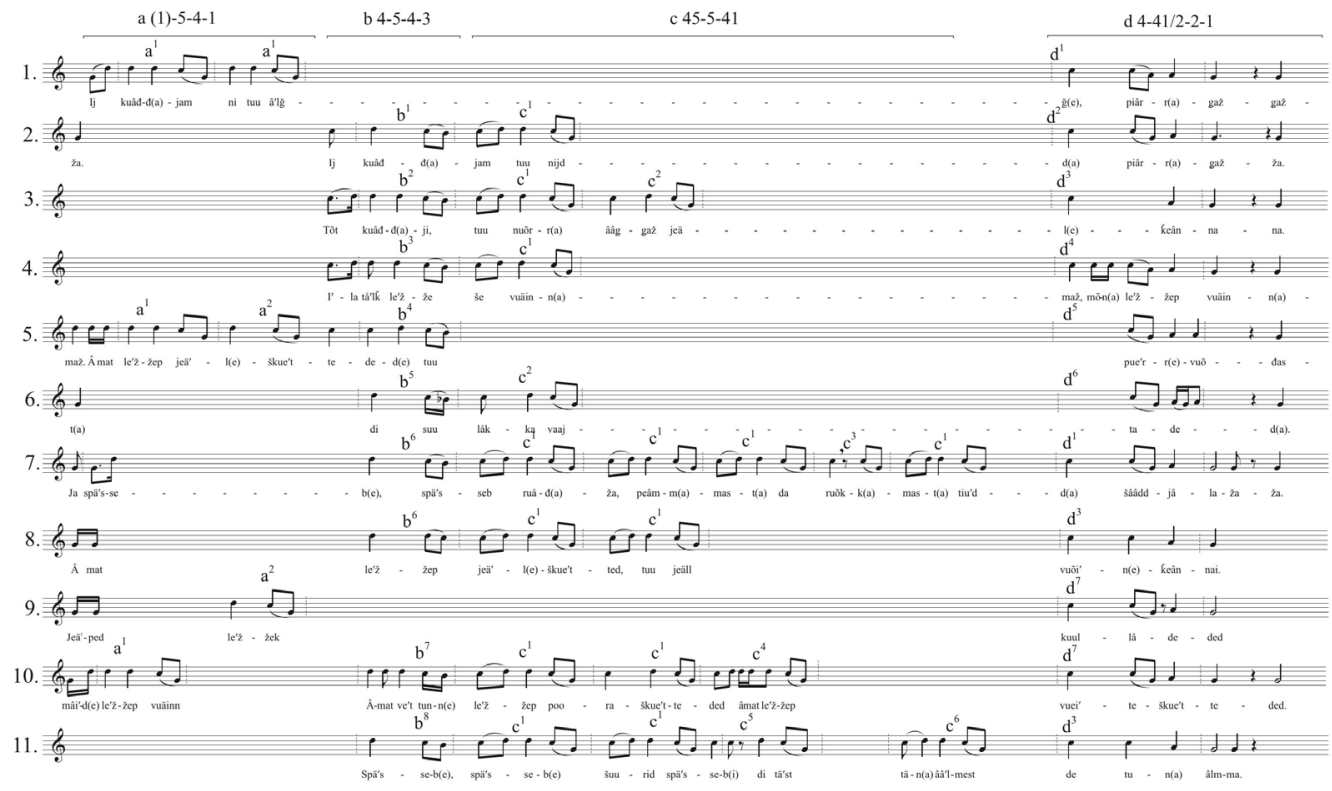

Nuottiesimerkki 1. SKS KRA. L 277a. Tekstin transkriptio ja suomenkielinen käännös: Elias Mosnikoff, Seija Sivertsen, Markus Juutinen ja Marko Jouste. Nuotinnos Marko Jouste.

Esitys rakentuu musiikillisesti neljälle melodia-aiheelle (a, b, c, d), joista koostuvaa laajaa säekokonaisuutta kerrataan. Tämä vastaa nuotinnoksessa yhtä riviä. Erityiseksi esityksen tekee siinä ilmenevä fragmentaarinen säerakenne (Jouste 2017, 75-79). Kyseessä on erityisesti kolttasaamelaisille leu'dd-sävelmille tyypillinen musiikillinen rakenne. Siinä säkeestä hahmottuu lukuisia melodia-aiheita, mutta melodiaa kerratessa näitä kaikkia ei välttämättä toisteta samassa järjestyksessä. Esittäjä siis valitsee fragmentteja pidemmästä säkeestä ennen kuin päättää kokonaisuuden lopukkeeseen ja pitkiin säveliin. Esittäjä voi myös kerrata aiheita. Nämä neljä melodia-aihetta näkyvät nuottiesimerkissä 2. Ensimmäinen, melodian aloittava aihe (Nuottiesimerkki 2. a) koostuu viidennen asteen sävelestä ja alaspäisestä hypystä neljänneltä asteelta perussävelelle. Toinen aihe (b) on edellisen variaatio, mutta perussävelen sijaan melodia laskeutuu kolmannelle asteelle. Kolmas aihe (c) on myös variaatio aiheesta a, mutta aiheen aloittaa asteittainen 4-5-liike. Säe päättyy aina perussävelelle johtavalle lopukkeelle. Tästä on kaksi variaatiota: 4-42-2-1 ja 4-41-2-1. 


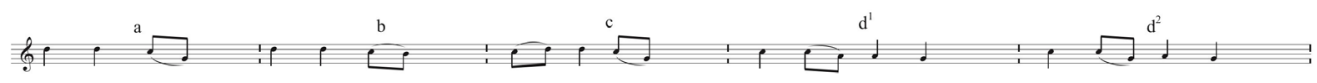

Nuottiesimerkki 2. Näskk Moshnikoffin esittämän kuolinitkun melodia-aiheet. sKs KRA. L 277a. Nuotinnos Marko Jouste.

Aiheita varioidaan runsaasti, erityisesti b- ja d-aiheet ovat erilaisia lähes joka kerta. Ne esiintyvät vain kerran yhden melodiasäkeen aikana siinä missä a- ja c-aiheet voivat kertautua. Varsinkin esityksen lopulla c-aihetta kerrataan lukuisia kertoja. Itkuesityksen fragmentaarinen säekokonaisuus näyttää seuraavalta:

\begin{tabular}{|l|l|l|l|l|}
\hline 1. & $\mathrm{a}^{1} \mathrm{a}^{1}$ & - & - & $\mathrm{d}^{1}$ \\
\hline 2. & - & $\mathrm{b}^{1}$ & $\mathrm{c}^{1}$ & $\mathrm{~d}^{2}$ \\
\hline 3. & - & $\mathrm{b}^{2}$ & $\mathrm{c}^{1} \mathrm{c}^{2}$ & $\mathrm{~d}^{3}$ \\
\hline 4. & - & $\mathrm{b}^{3}$ & $\mathrm{c}^{1}$ & $\mathrm{~d}^{4}$ \\
\hline 5. & $\mathrm{a}^{1} \mathrm{a}^{2}$ & $\mathrm{~b}^{4}$ & $\mathrm{c}^{2}$ & $\mathrm{~d}^{5}$ \\
\hline 6. & - & $\mathrm{b}^{5}$ & $\mathrm{c}^{2}$ & $\mathrm{~d}^{2}$ \\
\hline 7. & - & $\mathrm{b}^{6}$ & $\mathrm{c}^{1} \mathrm{c}^{1} \mathrm{c}^{1} \mathrm{c}^{3} \mathrm{c}^{1}$ & $\mathrm{~d}^{1}$ \\
\hline 8. & - & $\mathrm{b}^{6}$ & $\mathrm{c}^{1} \mathrm{c}^{1} \mathrm{c}^{4}$ & $\mathrm{~d}^{7}$ \\
\hline 9. & $\mathrm{a}^{2}$ & $\mathrm{~b}^{7}$ & - & $\mathrm{d}^{2}$ \\
\hline 10. & $\mathrm{a}^{1}$ & $\mathrm{~b}^{8}$ & $\mathrm{c}^{1} \mathrm{c}^{1} \mathrm{c}^{4}$ & $\mathrm{~d}^{7}$ \\
\hline 11. & - & $\mathrm{b}^{8}$ & $\mathrm{c}^{1} \mathrm{c}^{1} \mathrm{c}^{5} \mathrm{c}^{6}$ & $\mathrm{~d}^{3}$ \\
\hline
\end{tabular}

Taulukko 1. Näskk Moshnikoffin esittämän kuolinitkun fragmentaarinen säekokonaisuus.

Fragmentaarista säerakennetta voidaan hahmottaa myös siten, että määritellään "säännöt" siihen, miten aiheesta toiseen voidaan edetä. Tämän esityksen säännöt ovat: a-säe voidaan kerrata, a:sta voidaan siirtyä suoraan b- tai d-säkeeseen, mutta ei c-säkeeseen. B:tä ei voi kerrata, mutta siitä voidaan siirtyä suoraan c- tai d-säkeeseen. $C$ voidaan kerrata, ja siitä voidaan siirtyä suoraan vain d-säkeeseen. D:tä ei voi kerrata, ja siitä voidaan siirtyä suoraan a- tai b-säkeeseen. Olennaisia ovat myös säännöt siitä, mitä ei melodiassa voi tehdä. Fragmentteja ei voi valita siten, että sävelmän lopusta liikuttaisiin kohti alkua. B-säkeestä ei voi siirtyä a:han, c-säkeestä b:hen tai d-säkeestä c:hen. Uuden säkeen alkuun pääsee vain päättämällä edellinen säe lopukkeeseen.

Myös säkeistä toisiin siirtymiset ovat mielenkiintoisia. Siirtymä tapahtuu jokaisella kerralla eri tavalla. Säkeiden lopussa on tauko, jonka aikana esittäjä to- 
dennäköisesti hengittää, vaikka tämä ei kuulu selvästi äänityksessä olevan rahinan takaa. Tauon jälkeen melodia lähtee perussäveleltä ja kertautuu tai hyppää suoraan neljännelle tai viidennelle asteelle kohotahdin omaisesti, jonka jälkeen alkaa joko a- tai b-aihe. Varsinkin a- ja b-säkeissä kohot limittyvät varsinaisen aiheen kanssa siten, että aihe supistuu kahden iskun mittaiseksi. Sanojen tavumäärän vaihtelu vaikuttaa aiheiden rytmiin.

Yllä oleva itkuvirsi ja kuvaus itkutilanteesta liittyvät kokonaisuudessaan 190o-luvun alkupuoliskon Suonikylän kulttuuriseen tilanteeseen, mutta kolttasaamelainen itkuperinne jatkui myös toisen maailmansodan jälkeisen evakon ja uudelleenasuttamisen jälkeen. Itkuperinteeseen viitataan haastatteluissa, ja esimerkiksi Heikki Laitisen haastattelema Sevettijärvellä terveydenhoitajana työskennellyt Paula Feodoroff kertoi vuonna 1973 omakohtaisesta kokemuksesta kuullessaan itkuja seuraavasti:

Jos on sattunu kuolemantapaus kotona, ja olen ollu siellä, suvun vanhat naiset tulevat välittömästi, kun kuolemantapaus on sattunut, kutsutaan paikalle, niin olen pari kertaa kuullut tämmösen spontaanin itkuvirren ja minusta se oli valtava elämys. No siitä tilanteesta ensinnäki, että tää oli semmonen yli kahdeksankymmentävuotias vanha mummo, joka oli kuollu ja tää vainaja lepäs lattialla ja siinä oli tään vainajan miniä ja suvun naisia, vanhoja naisia, jotain kaks kolme kappaletta siinä ympärillä. Miehet istuivat tai seisoivat tuvan toisella puolella ja naiset itkivät. Vanhin alotti se jotenkin hyvin korkealla kimakalla äänellä ja siihen toiset sitten yhtyivät ja semmonen nouseva laskeva rytmi oli siinä ja jotenki semmonen tunnelma että mää ajattelin että täytyy olla kiitollinen, että sai olla mukana siinä, vaikka ulkopuolisena kuitenkin mutta jotenkin siinä mukana --Kaikki se semmonen, pieni hämärä tupa ja miehet siellä, sieltä kuulu vaimeita nyyhkytystä sieltä miesten puolelta ja sitten se vaimojen paikoin kimeä paikoin sitten semmonen valittava rytmikäs joikuminen. Ilmeisesti siinä kerrottiin tästä vainajasta ja hänen elämästään ja miten nyt jätti, jätti poikansa ja miniänsä ja sukulaisensa ja lähti jonneki muualle. (Laitinen 1977: 47-48.)

Kuvauksesta käy ilmi, kuinka omaiset toimivat itkutilanteen aikana. Kiinnostavaa on, että itkutilanteessa läsnä olevilla on selkeät roolit. Vanhin nainen johtaa itkua ja muut liittyvät mukaan vasta tämän aloitettua. Myös "nouseva-laskeva" rytmi sopii hyvin yllä olevaan Näskk Moshnikoffin itkun sävelmän luonteeseen. 
Kyseessä onkin suora jatkumo Suonikylän itkuperinteelle, sillä Sevettijärvelle asutettiin juuri Suonikylän asukkaat.

\section{Hääitku: morsian hyvästelee vanhempansa}

Kuolemantapauksen ohella toinen yhteisöllinen itkutilanne liittyi häihin. Suonikylässä 1900-luvun alussa häät pidettiin tavallisimmin morsiamen kotona ja juhlallisuudet kestivät kolme päivää. (Itkonen 1948 II: 413-425). Kolttasaamelaisissa häissä kuultiin tavallisesti vain yksi itku, jolla morsian hyvästeli vanhempansa ja lapsuuden kotinsa. Tältä osin kolttasaamelaiset häät poikkeavat karjalaisista häistä, joihin kuului lukuisia itkuvirsiä eri tilanteisiin (ks. esim. Honko 1963: 116). Väisänen kuvailee kolttasaamelaisen morsiamen itkun esitystilannetta siten, että ennen morsiamen lähtöä miehen kotiin sulhanen ja morsian istuvat oven suussa yhteisen hunnun alla. Lähtöhetkellä morsiamen ristiäiti eli kummi menee morsiamen vasemmalle puolelle istumaan. Silloin morsian rupeaa itkemään vanhempiaan, sisariaan, veljiään. Mutta jos morsian ei itse ole "sanantaitaja", kukaan muu ei itke hänen puolestaan. (sKS KRA. A. O. Väisäsen kokoelma. Kotelo 6: Petsamo 1926.) Seuraavassa tarkastelen Väisäsen Suonikylässä vuonna 1926 äänittämää Näskk Moshnikoffin esitystä, joka on ainoa morsiamen itkuksi nimetty tallennus (SKS KRA. A503/15). Teksti on seuraavanlainen: 
Tekstiesimerkki 2. SKS KRA. A503/15. Tekstin transkriptio ja suomenkielinen käännös: Elias Mosnikoff, Seija Sivertsen, Eino Koponen, Miika Lehtinen, Markus Juutinen ja Marko Jouste.

De pä'sseb šõõddâž, njeě̌žă̌

poor-a-te'm-e-sted-e, teâv-a-te'-m-e-sted

tiudd-a råå'pp-e räjja.

Jeä'ped-e poor-a-tam ni sää'lt-e-'te'mes-õ,

kåårn-e-te'mes veä-veärain de de.

Kuâđđ-a-je'ǩed-e, pää'cced-e tiõrvân, tiõrvân-a.

A, tot leežž-a, kuâđđ-a-jed-e, pää'cced

åår-a-ste'ǩked, šõõdd-â-žam, nježž-e-žam-a

Vaa'ldi go kuäđaž, kuäđaž-a.

Kuâđđt-a-je'ked, pää'cced-e tiõrvân-a

viillj-a-žan- $a$, vuäbb-a-žan- .

Pä'sseb, pä'sseb-e, šõodd-â-žam:

jiõm-a kõõlm-a-stõõllâm- $a$,

jiõm koolg-a-tõõllâm-a.

Pä'sseb, pä'sseb-e, njeě̌ž- $a$-žam-ma,

ruõ'ǩkik, piõmmuk-a tiiud-a råå'pp räjj-räjja.

De go tõt leežž-a pä̈̈'cced-e nijdd-a.

Mun vaa'ldi jo âl-

jo ââlgaž-a.

Go kiõččam jie'llem-a jååtted-ed

na tõt leežž-a kuâđđ-a-jed nijdd-a

pie'cc-e severnaja jeäll-a

jeäll-a årra e'ččce, jie'nn-e va'lede kuâđaž.

Kuâđt-a võl-a di

kuâđd-a-je'ked-e pää'cced-e

tiõrvân ruåd-a-žan-a vu'vdd.
Niin kiitos kasvattajainen, emonen

syöttämisestänne, vaatettamisestanne

täyteen vartaloon asti.

Ette syöttäneet suolattomalla

jyvättömällä ruo-ruoalla niin.

Jääkää hyvästi, pysykää terveinä, terveinä.

Kas, se lienee, jääkää jääkää,

viipykää hetki, kasvattajaiseni, emoseni

Otti kun kotanen, kotanen.

Jääkää hyvästi, pysykää terveinä,

veliseni, siskoseni.

Kiitos, kiitos kasvattajaiseni:

en kylmistellyt,

en kuljetellut.

Kiitos, kiitos emoseni,

hoidit, ruokit täyteen vartaloon asti-asti.

Ja kun se lienee jäämässä tyttö.

Minut otti poi-

jo poikanen.

Kun katson elämän kulkemista.

Niin se jäänee tyttö.

Mänty pohjoinen elää,

elää luona isän, äidin valtakotasen.

Kotaan vielä ja

jääkää jääkää

terveenä suku(inen) alue. 
Itkun sisältönä on morsiamen oma kuvaus siitä, kuinka hänet on otettu vaimoksi ja hän on jättämässä lapsuuden kotinsa. Morsian kiittää vanhempiaan elättämisestä täysikasvuiseksi eli "täyteen vartaloon asti" ja siitä, että vanhemmat eivät syöttäneet suolatonta tai jyvätöntä ruokaa. Itkurunoon kuuluvat myös hyvästit ja terveen elämän toivotukset vanhemmille ja sisaruksille.

Morsiamen itkun melodia koostuu 24 säkeestä (Nuottiesimerkki 4). Melodia rakentuu lyhyelle ja varioivalle aiheelle (a), joka päättyy säkeen lopukkeessa perussävelelle. Myös tässä aiheitta varioidaan ja kerrataan fragmentaarisen säerakenteen mukaisesti. Valtaosa aiheista koostuu laskevasta kvarttihypystä 4-1, joka voi täydentyä myös välisävelillä tai tihentyä saman sävelen toistolla (4-1, 4-11, 4-41, 4b3-1, 44-b31, 4b3-11, 4b3-b31). Muutaman kerran aihe esiintyy myös terssihyppynä (b3-b31). Aiheiden välissä on siellä täällä muutaman sävelen ryhmä, joka ikään kuin sitoo aiheita toisiinsa. Aihetta toistetaan yleensä kaksi kertaa, minkä jälkeen melodiassa seuraa lopuke. Osassa säkeistä aihe toistuu useampiakin kertoja. 


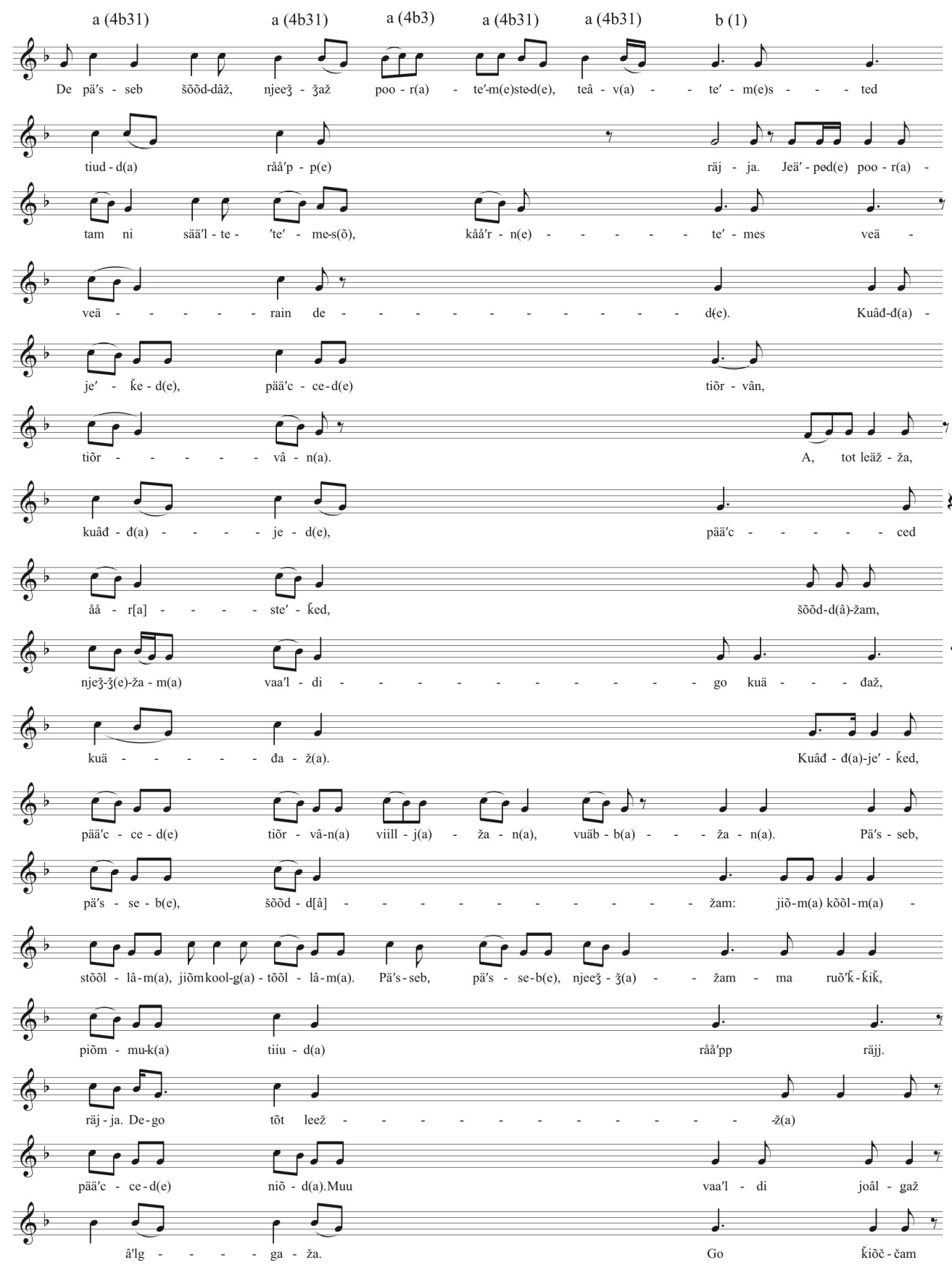

Nuottiesimerkki 4. SKS KRA. A503/15. Tekstin transkriptio ja suomenkielinen käännös: Elias Mosnikoff, Seija Sivertsen, Eino Koponen, Miika Lehtinen, Markus Juutinen ja Marko Jouste. Nuotinnos Marko Jouste. 
Kahden edellä kuvatun esimerkin, Näskk Moshnikoffin esittämien hää- ja kuolinitkun perusteella voidaan sanoa, että itkumelodian erityispiirteenä ovat lyhyet ja perussävelelle laskeutuvat aiheet. Itkusävelmä erottuu esimerkiksi kolttasaamelaisista leu'dd-melodioista siten, että leu'ddien kertautuvat sävelmät ovat yleensä huomattavasti pidempiä ja koostuvat yhdestä, kahdesta tai kolmesta säkeestä. Useampisäkeisissä sävelmissä lopukkeet myös poikkeavat usein toisistaan. Yhteisenä piirteenä esiintyy fragmentaarinen säerakenne. Osa leu'ddeista perustuu myös esimerkiksi venäläisille lauluille, jolloin säerakenteet varioivat maltillisemmin (vrt. Jouste 2017: 78-81).

Hääitkuaineistoa täydentää kolttasaamelaisen musiikkiperinteen tärkeä osa eli niin sanotut kosinta-leu'ddit (vuâttum leu'dd). Kun päähenkilönä on nainen, tekstissä kuvataan usein kosintatilannetta, jossa hän tekee päätöksen avioitua. Tekstin sisältö voi liittyä myös itse häätilanteeseen, jossa morsian on jättämässä lapsuudenkotinsa ja hyvästelee vanhempansa. Tämä onkin juuri sama tilanne, johon morsiamen itku liittyi, ja onkin luonnollista, että joissain leu'ddeissa viitataan suoraan myös tähän itkuun. Tällainen on esimerkiksi Näskk Moshnikoffin esittämä Fedoran leu'dd vuodelta 1961 (Kper AK/o548). Arkiston tallennustiedoissa viitataan myös tähän itkutilanteeseen: "Feodora Kiprianoffin eli miehelään lähtevän nuorikon joiku; kiittää itkien vanhempiaan."

Leu'ddissa morsian kysyy ensin isältään, miksi hänet on naitettu vanhalle leskimiehelle. Morsian ei kuitenkaan soimaa isäänsä vaan kertoo, että hän teki itse oman päätöksensä hyvien puhemiesten, ei kihlalahjoina olleiden koreiden huivin ja hameen takia. Itkosen mukaan 1900-luvun alun Suonikylässä lahjoihin kuuluivat juuri silkkihuivi, hamekangas, hopea- tai kultasormus, helmiä ja rahaa (Itkonen 1948 II: 419). 
Tekstiesimerkki 3. Kper AK/o548. Tekstin transkriptio ja suomenkielinen käännös: Eino Koponen, Markus Juutinen ja Marko Jouste.

Mõõzz muu leäk šõõddâž juukk-â-mâž?

Mõõzz-e go leäskka puä'res vuõdd-a-mõ'žže,

Piâtta'že Råmman ââlga Ko'sten?

Kuuđlåå'ǩk ekk-a-saž-a, sue'bbin-i va'33-e-jaž.

Jiõm le'jje niõđâž ni vue'lğğed-ed

ni bumažnai heä'rvv-e-reepp-a-kai diõtt-a.

Ni jiõm le'jje vue'lğğed-ed,

ni Daackai heä'rvv-e-kååuti diõtt-a.

Da ni ja mon ve't-e pâi ja vuâlgam-a

pue'ri suõnn-a-poo'nn'-e-jie diõtt.

\section{Veâl-a Teäppan vuänak}

lij kää'lles Ko'rnel â'lğğ, â'lğğ-e.

Meedrai-maakkâm Ǩiu'rrel â'lğğe,

da a ma't le'žžem mon de

de-e de juõ’ǩk jiõm-ma tie'đ-e koozz-a.

Spä'sseb-e vuänak spä'sseb-e Vue'lljäu'rr ääkkaž

nue'tt-e tu'nne võõrâs-a kue'l-e-stad.

Šõõdd-â di spä'sseb-e, spä'sseb šõõddâž

Ko'sten â-â'lğğe,

ǩiuggân-i meäkkai leei'b-e-stad-a

di ja sam-o-var pakk-a čee-'je-stad.

Šõõdd-â di jiõk poor-a-muu-tam niõđ-e,

ni sää'lt-e-te'mes, kåå'rnte'mes-e veärain.

Ruõ'̌̌ǩkik-e muu niõđa ruõ'̌̌kik

tiudd-sa tiõrvv-õ-sa.

tiudd muu råå'pp-e räjja.

Tõõzz le'žže kuâđđ-a-jed Vue'lljääu'r g-ääkka veâlla

Vuâlgažom.
Miksi minut olet isäni juonut?

Miksi kun leskelle vanhalle miehelle,

Pikku-Pekan Rommanin pojalle Kostille?

Kuusikymmentävuotinen, kepillä kävelijäinen.

En olisi tyttönen edes lähtenyt

edes pumpulisen korean huivin takia.

Minä en olisi lähtenyt,

en Norjan korean hameen takia.

No en ja minäpä vain ja lähden

hyvien puhemiehien takia.

Vielä Teäppan näköjään

on ukko Kornelin poika, poika.

Mitrji lanko Kiurelin poika

ja miten olisin minä niin

niin niin, joka en tiedä minne.

Morsiamen itkun sitaatti:

Kiitos, näköjään, kiitos Vue'lljäu'rr-akkanen

nuotta-sinun-tuoreesta kalasta.

Kiitos ja kiitos, kiitos kasvattajainen Kosten poika, uunituoreesta leivästä.

ja ja samovaarikuumasta teestä.

Kasvattaja ja et syöttänyt minua tyttöä,

et suolattomalla, jyvättömällä ruualla.

Säilytit minun tytön, säilytit

täyteen saakka terveeseen saakka,

täyteen minun vartaloon asti.

Siihen jäänee Vue'lljäu'rr-akkanen vielä.

Lähtisin. 
Itkuperinteen tutkimisen kannalta on kiintoisaa, että leu'ddin loppuosassa on jakso, jossa on sama kiittelyyn liittyvä tekstisisältö kuin edellisessä morsiamen itkussa. Morsian kiittää vanhempiaan, että he kasvattivat tyttären "täyteen ja terveeseen vartaloon" asti, eivätkä syöttäneet "suolattomalla" ja "jyvättömällä" ruualla ja että hän sai syödä kotona "uunituoretta" leipää, "nuottatuoretta" kalaa ja "samovaarikuumaa" teetä.

\section{Rekryytti-itku: sotaan lähtevän miehen hyvästely}

Kolmanteen pääteemaan kuuluvat rekryytti-itkut, joilla sotaan tai asepalvelukseen lähtevän miehen äiti hyvästelee poikaansa. Rekryytti-itkut kuuluvat rituaalisiin itkutilanteisiin. Perinne sai alkunsa todennäköisesti 170o-luvulla, kun Venäjällä vakinaistettiin pitkäaikainen, jopa 25-vuotinen asepalvelus ja armeijaan alettiin määrätä nuoria miehiä tavallisen kansan keskuudesta (Asplund 2006: 81, 96-98; Honko 1963: 123-124). Asepalvelus koski luonnollisesti myös kolttasaamelaisia, jotka kutsuttiin ensimmäisen maailmansodan aikana Venäjän armeijaan. Esimerkiksi Jääkk Sverloff, Suonikylän pitkäaikainen kylänvanhin, oli kuusi ja puoli vuotta sotaretkellä ensimmäisessä maailmansodassa ennen kuin pääsi palaamaan rintamalta kotiin (Linkola 1985: 99).

Miesten asepalvelukseen tai sotaan lähtemisen yhteydessä sotilaan äiti ja sisaret itkivät. Väisänen kirjoitti vuoden 1926 matkalla: "Sotaan lähtiessä: äiti itkee; jollei [ole] äitiä niin sisar. - - Kun on saatu varma tieto kaatumisesta, itketään taas." Kysymys on siis pohjimmiltaan siitä, että varauduttiin sotaan lähtevän kuolemaan ennakolta. (sKs KRA. A. O. Väisäsen kokoelma. Kotelo 6: Petsamo 1926; ks. myös Laitinen 1977: 47-52.) Lati Feodoroffin mukaan rekryytti-itkujen sisältönä oli sotilaaksi lähtevän hyvästeleminen, hänen kaipaaminen ja paluun odotus (Feodoroff h2020). Rekryytti-itkuista ei ole toistaiseksi löytynyt tallenteita, joten niiden täsmällistä sisältöä ei voi käsitellä tämän tarkemmin. 


\section{Tilapääitkut 1: kaipuu menetetyille asuinpaikoille}

Tilapääitkut liittyvät itkutilanteisiin, joiden avulla itkijä käsittelee henkilökohtaisen elämän vaikeuksia ja surua sekä läheisten ihmisten raskaita kohtaloita (Asplund 2006: 98; Stepanova, E. 2009: 13). Kyse ei siis ole rituaalisesta tilanteesta. Kolttasaamelaisista aineistoista ei toistaiseksi ole ollut mahdollista tunnistaa kuin muutamia itkuja, jotka liittyvät esittäjien henkilökohtaisiin elämäntapahtumiin. Tällaisia ovat esimerkiksi kaksi kiitositkua, joista toisen esittelen tuonnempana. Laajin temaattinen ryhmä sisältää evakkoon ja menetettyjen kotipaikkojen muisteluun liittyviä esityksiä. Lati Feodoroffin mukaan juuri nämä voidaan sisällön ja esitystavan perusteella tulkita itkuiksi, koska niillä hoidettiin omaa tai läheisten surua (Feodoroff h2020). Monet näistä esityksistä voidaan liittää itkuperinteeseen myös tekstin ja musiikin rakennepiirteiden kautta. Kolttasaamelaisen perinnemusiikin terminologia ja erityisesti leu'ddien ja itkujen suhteen selvittäminen vaatii vielä lisätutkimusta.

Arkistoluetteloissa tässä tilapäätikuiksi tulkitsemieni tallenteiden nimenä on useimmiten joiku, jota on tarkennettu sisältöön liittyvällä kuvauksella, esimerkiksi "Joiku Petsamoon jääneestä kotiseudusta" (Kper AK/o871) tai "Siirtolaisjoiku uusille asuma-alueille muutosta huhtikuussa 1949" (Kper AK/o526; Jouste et al. 2007: 73). Kuten aiemmin mainitsin, joiku-sanaa käytettiin keräyksessä yleisnimityksenä kaikenlaiselle saamelaiselle perinteelle, eikä se sulje pois mahdollisuutta tarkastella perinteenlajia täsmällisemmin uuden, tarkemman tiedon valossa. Vanhojen asuinpaikkojen muistelun yhteys suruun saattaa tulla esiin myös haastattelussa. Esimerkiksi suonikyläläinen Ååjjaž Fofanoff aloitti Mikko Korhosen haastattelussa vanhaa asuinpaikkaa käsittelevän leu'ddin Suõ'nn'jel sijdd 'Suonikylä', mutta keskeyttää heti esityksen ja toteaa, että "mutta itku kuitenkin tulee, ei se haittaa, minä en, panen surut pois" (sKNA 09839a).

Seuraavissa kahdessa esimerkissä käsitellään kaipuuta menetetyille asuinpaikoille ja evakkomatkaa. Ensimmäisessä, Dä'rjj Jefremoffin esittämässä itkussa (Kper AK / 0871) muistellaan Suonikylän vanhan asuinpaikan tarjoamia hyviä elinmahdollisuuksia ja kerrotaan, kuinka raskasta oli jättää kotiseutu, kun piti siirtyä sodan alta pois. 
Tekstiesimerkki 4. Kper AK/0871. Tekstin transkriptio ja suomenkielinen käännös: Elias Mosnikoff, Seija Sivertsen, Markus Juutinen ja Marko Jouste.

Vuõi muu šââdd-a g-Ääkkajääur ääkkaž

Pä'sseb, ruõ'ǩǩik̆ tiõrvv-õ-sa.

Â mat le'žžem kue'đđed-ed, vue'lğğed-ed.

zagranična lo'sses määtkaž.

Tõt leežž šiõrr-a hää'š̌es pääikaž.

Kuâđđ-a-je puäz3-e hää'š̌es vue'jj-â

mooččâs võõnâs, säi'mm-ä, võõrâs kuâlaž.

Tõk le'žže puk kue'đđed-ed tuâj.

Ǩiirâs jiânnai, tobddâz jiânnai.

Ku'̌̌es määtka vue'lğğed

di lossâd väi'vv leäi je vä'ldded-ed

vuä'mm-e n-iiss-a, vuä'mm-e jeä'nn

Â, mat le'žžem vuei'tted-e jåå'tted?
Voi minun syntymä Akkajärvi-akkanen.

Kiitos, ruokit terveeksi.

Aivan kuin olisin jättänyt, lähtenyt.

Rajantakainen raskas matkanen.

Se lienee leikki-hauska-paikkanen.

Jäivät poro-hauska-ajelu,

kaunis vene, kalaverkko, tuoreet kalaset

Ne olisivat kaikki jääneet työt.

Kiirettä paljon, tuttuja paljon.

pitkä matka lähteä

ja raskas ponnistus oli ottaa

vanha isä, vanha äiti.

Mitenköhän olisin voinut kulkea?

Suonikylän aluetta ja sen tarjoamia elinmahdollisuuksia kuvataan ilmauksilla kuten: "kalaisat järvet, kauniit veneet, hyvät kalaverkot, tuoreet kalat". Nämä ovat vastaavanlaisia ilmaisuja kuin aiemmin esitellyssä morsiamen itkussa. Itkuihin esityksen liittää myös lause, jossa kiitellään kotipaikkaa ja kuinka se ruokki terveeksi: Pä'sseb, ruõ 'ǩkik tiõrvv-õ-sa 'Kiitos, ruokit terveeksi'. Kiittelyn lisäksi myös runsas deminutiivien käyttö (määtkaž 'matkanen', pääikaž 'paikkanen', kuâlaž, 'kalanen') kiinnittää tekstin itkurunouteen. Tekstin kolmannessa osassa kuvataan kotiseudun jättämistä, kun edessä on zagranična lo'sses määtkaž 'rajantakainen raskas matkanen' Suomeen. Kiinnostavasti Dä'rjj Jefremoff käyttää tässä yhteydessä venäjänkielestä lainattua sanaa zagranična 'rajantakainen', jolla viitataan nimenomaan vanhaan Venäjän rajaan, joka erotti Suonikylän Suomesta. 


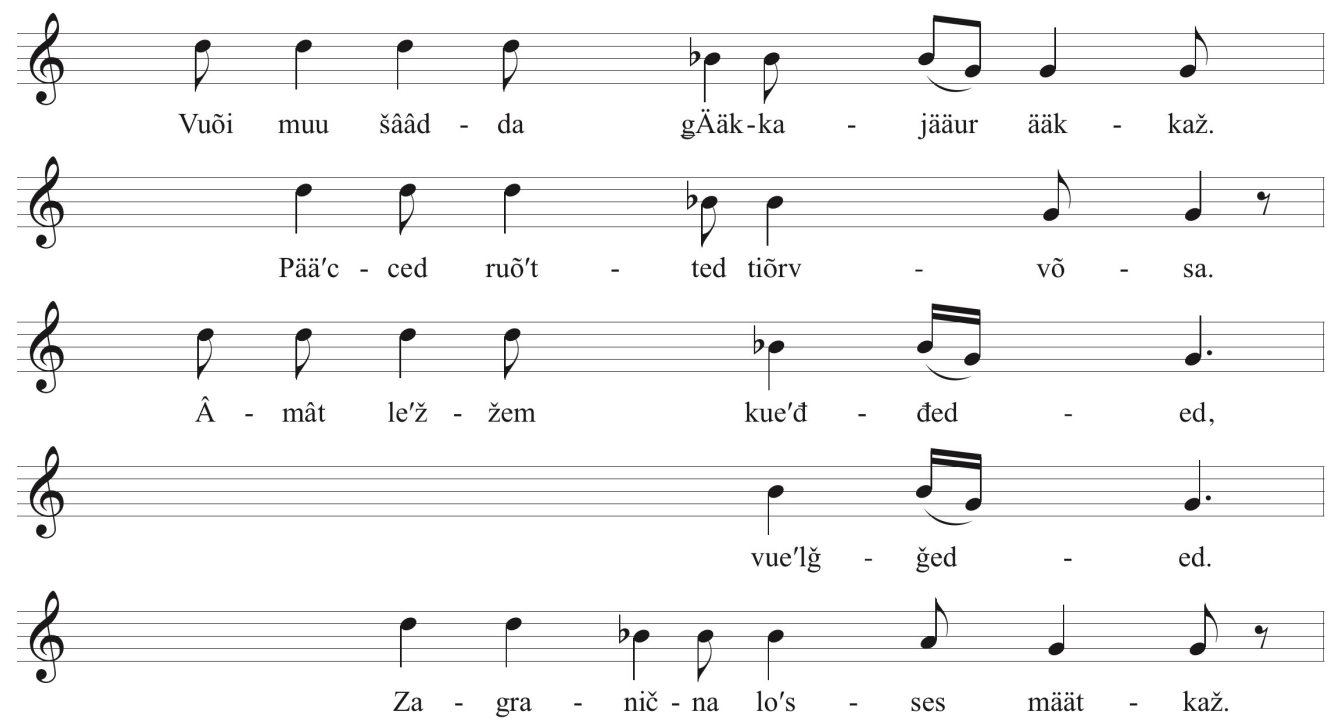

Nuottiesimerkki 5. Kper AK/o871. Katkelma Dä'rjj Jefremoffin esityksestä. Tekstin transkriptio ja suomenkielinen käännös: Elias Mosnikoff, Seija Sivertsen, Markus Juutinen ja Marko Jouste.

Nuotinnos Marko Jouste.

Esityksen melodia koostuu laskevista säkeistä (5-b3-1), jotka toistuvat koko esityksen ajan. Säkeiden pituus vaihtelee, mutta niiden laskeva aihe ei ole ihan niin lyhyt ja rytmikäs kuin edellä esiteltyjen Näskk Moshnikoffin itkujen sävelmissä.

Samankaltaista aihepiiriä käsittelee U'lljan Fofanoffilta vuoden 1961 esitys (Kper AK/0561; Jouste et al. 2007), jossa kuvataan viiden vuoden mittaisen evakkomatkan viimeistä osuutta ennen asettumista Sevettijärvelle. Matka tehtiin Inarijärven jään yli keväällä 1949. Sevettijärvi tunnettiin tuolloin Näätämö-nimellä, sillä se oli ollut Näätämön kolttasaamelaissiidan talviasuinalue ennen vuoden 1826 rajanvetoa (Jouste et al. 2007: 74). 
Tekstiesimerkki 5. Kper AK/0561. Tekstin transkriptio ja suomenkielinen käännös: Elias Mosnikoff, Seija Sivertsen, Markus Juutinen ja Marko Jouste. Nuotinnos Marko Jouste.

\author{
Juõvv-a-pä'htt-e lij Njauddâmsijdd-ääkkaž \\ di juõvv-a-pä'htt Njauddâmjokk siidâž. \\ Mij leä'p puätt-a-maž, mij leä'p puätt-a-maž \\ mâ'te käirrav õ'š̌k låådda-da \\ pâi juõvi paau'ti g-õ'š̌ǩe-[he] jo sizz.
}

\author{
Louhikko-pahta on Näätämösiida-akkanen \\ ja louhikko-pahta Näätämöjoki siidanen. \\ Me olemme tulleet, me olemme tulleet \\ kuin kajavat konsanaan, lintuset \\ kuin louhikko-pahtojen konsanaan jo sisään.
}

Sevettijärven uutta asuinpaikkaa kuvataan ilmaisulla juõvv-a-pä'htt-e 'louhikkopahta', johon kolttasaamelaiset ovat tulleet kuin kajavat kalliolle. Esitys on hyvin lyhyt ja todennäköisesti katkelma pidemmästä kokonaisuudesta, sillä U’lljan Fofanoff lopettaa esityksen sanoin "Emmie jaksa ennää". Arkistotallenteilta löytyy myös pidempiä esityksiä, joissa kerrotaan yhtenä kokonaisuutena samankaltainen tarina kuin näissä kahdessa erillisessä esimerkissä.

Esitys sisältää vain kolme säettä, jotka muistuttavat rakenteeltaan edellisen esimerkin säkeitä, vaikka ovatkin pidempiä. Säkeen rakenne voidaan analysoida koostuvaksi kolmesta osasta: Melodia lähtee perussäveleltä, hyppää sitten keskiosaan, jossa liikutaan kolmella sävellellä $\left(5,4, b_{3}\right)$ ja lopuksi palaa perussävelelle 4-b3-1-liikkeellä. Keskiosa on kaikissa kolmessa säkeessä erilainen, mutta koostuu samankaltaisista muutaman sävelen mittaisista melodia-aiheista (5-4-b3-4, 5-4-b3, 4-b3), jotka hahmottuvat sanojen mukaan. Melodia on vapaarytminen.

A
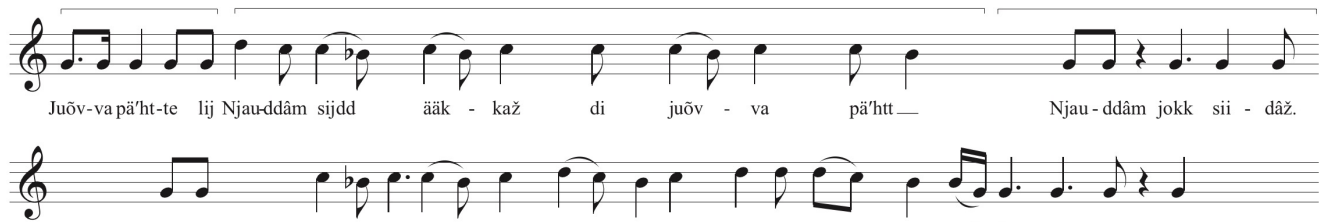

Mij leä'p puät - ta-maž, mij - leä'p puät - ta-maž mâ' - ta käir

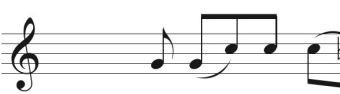

pâi juõv - vi pääu
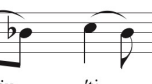

- õ'š̆
C

Nuottiesimerkki 6. Kper AK/0561. U'lljan Fofanoffin esittämä Njauddâm sijdd. Nuotinnos Marko Jouste. 


\section{Tilapääitkut 2: kiitollisuuden osoittaminen itkulla}

Evakko-aiheen lisäksi itkuperinteeseen viittaavia piirteitä löytyy sellaisista esityksistä, joiden pääasiallisena sisältönä ovat läheisille osoitetut kiitokset. Tämä tunnetaan myös läheisistä itkuperinteistä, ja kiitoksen kohteina voivat olla esimerkiksi perinteenkerääjät (Asplund 2006: 98). Dä'rjj Jefremoffin vuonna 1955 esittämä kappale kuvaa hänen itsensä ja Näskk Moshnikoffin matkaa Sevettijärveltä Helsinkiin esittelemään kolttasaamelaisen perinneraanun tekoa Seurasaaren ulkomuseoon (Kper AK/o864).

Tekstiesimerkki 6. Kper AK/o864. Tekstin transkriptio ja suomenkielinen käännös: Marko Jouste, Markus Juutinen ja Eino Koponen.

Kaopoykast

Tä'st kiiiččee, sââgg-a-stââll.

Pä'sseb šõõdd-â-žam Feäđat â'lğğg,

pä'sseb njeežž-a-žam Feäđat nijdd.

Ruõkkiid, kaa'ggiid

tiudd-e rååpp-a-že.

Muи leä'ped ǩiessam-a-ža da tän jõnn

muи kaoponkii vuei'nnem-he-nalla.

Kookkas lij kuâđđ-a-jam

šâdd-a Äkkjääu'r ääkka

poostai pääi-kaž leäi-e vuõnnum

piõgg-a šuuvvanaž låå'-a-dd-e vill-a-naž.

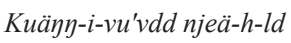

heä'rvv-e čiõggâr, jie'llemsââj-a-haž.

Pä'sseb ruåđid šõõdd-â-de-mest.

\section{Kaupungissa}

Tässä katselevat, keskustelevat [paikallaolijat].

Kiitos kasvattajaiseni Feäđatin poika,

kiitos emoseni Feäđatin tyttö.

Kasvatitte, nostitte

täyteen vartaloon.

Minut veitte tähän isoon

minut kaupunkiin nähtäväksi

Kauas on jäänyt

syntymä Akkajärven akkasen

autio paikkanen oli nähty

tuulen suhina, linnun viserrys.

Kuäyๆvu'vdd,

hieno tokka, asuinpaikka,

kiitos sukulaiset, kasvattamisesta. 
Mu'st I'llep nijdd vuäbba-haž lij.

Pä'sseb rää'ǩkes râ'dd-e ruå-huo-đaž.

Vuäinam jiõčč čââlma-ida-anvui'm

suu vaardâsvuõ'd-e,

suu čeâtnai ǩke'rjj-e-kiõđid.

Pä'sseb jeänn'-e-jaž leäk

ruõkkam-až-a suu jie'nnes heä'rvv-e

mooččâs-e jeäll-e-stemnääla.

Jiõm le'žže iilbažed,

jiõm muu'št-e iilbažed, vââjažed.

Rä̈̈'ǩkes muu šõodd-â-šid vuäbbaž,

mâ't le'ččep õ̃ut-a niõđ, I'llep niõđ.

Spä'sseb leäk jeä'l-e-tam

pâ'ss jie'llem ääkkaž

di pâ'ss-e pââibuž hiärr-a ââldâbuž.

Spä'sseb tän heä'rvv-e

Helsinǩi hää'š̌es jie'llemsââja.

Pä'sseb mij toobdâs kuâhttlo

kooum-â-lo ฤ-ee'jj šuuraž-e

Nickul puu'ti mi'jjid, kuâssta di

heä'rvv-e mi'jjid,

vie'ss-â-lõs jäl-e-stem sââjâž-e.
Minulla Illepin tyttö siskonen on.

Kiitos rakas rintasukulainen.

Näen itse silmineni

hänen ryhtinsä,

hänen taidokkaat kirjailu kätensä.

Kiitos enolle olet

säilyttänyt, hänen äidin hienon

kauniin elämäntapasen.

En olisi ilkeyttäsi,

en muista ilkeyttäsi, vihaasi.

Kasvatitte minun rakkaan siskoni,

kuin olisimme saman tyttöjä, Illepin tyttöjä.

Kiitos olet elättänyt

pyhä elämäakkanen

ja pyhä ylempi herra lähempänä.

Kiitos tästä koreasta

Helsingin hauskasta elinpaikasta.

Kiitos meidän tutulle kahdenkymmenen,

kolmenkymmenen vuoden takaiselle herrasellemme.

Nickul toi meidät, kestitsi ja

hauska meitä

iloiseen elämispaikkaan. 
Esityksen voi tulkita itkuksi, koska siinä on samoja tekstisäkeitä ja kiittelyjaksoja kuin muissa itkuteksteissä. Osansa kiitoksista saavat vanhemmat, sukulaiset ja erityisesti matkan järjestäjänä toiminut suomalainen Karl Nickul, joka tutustui kolttasaamelaisiin jo 1930-luvulla Petsamossa. Myös yleisesti "elämää" ja taivaan herraa kiitetään viittaamalla näihin metaforisilla ilmaisuilla $p \hat{a}$ 'ss jie'llem ääkkaž 'pyhä elämäakkanen' ja pấss-e pââibuž hiärr-a ââldâbuž 'pyhä ylempi herra lähempänä'.

\section{Kolttasaamelaisten itkujen kielellisiä erityispiirteitä}

Seuraavaksi tarkastelen kolttasaamenkielisten itkujen kieleen liittyviä ilmauksia sekä rakenteellisia ja tyylillisiä piirteitä. Yleinen huomio on, että kolttasaamelaisten itkujen kieli ei näytä muodostavan täysin selkeästi itsenäistä tyylillistä kokonaisuutta. Selkein tyylillinen malli on kolttasaamelainen leu'dd-kieli (vrt. Jouste et al. 2020).

Kenties kaikkein tunnistettavin kolttasaamelaisen itkukielen sisällöllinen piirre on kiitteleminen. Kuolinitkuissa vainaja kiittää hyvin hoitamisesta ja hautaamisesta, hääitkuissa morsian kiittää isäänsä siitä, että kasvatti hänet täyteen vartaloon asti eli aikuiseksi, esimerkiksi: Pä'sseb, pä'sseb-e, šõõdd-âa-žam 'Kiitos, kiitos kasvattajaiseni', Pä'sseb šõõdd-â-žam Feäđat â'lğğ 'Kiitos kasvattajaiseni Feäđatin poika', pä'sseb njeě̌ž-a-žam Feäđat nijdd 'kiitos emoseni Feäđatin tyttö'.

Itkuissa vanhemmista käytetään usein puhekielestä poikkeavia kiertoilmauksia. Puhekielen sanan $e^{\prime c ̌ c ̌ ~ ' i s a ̈ ' ~ s i j a s t a ~ o n ~ l e u ' d d e i s s a ~ t y y p i l l i n e n ~ s a n a ~ s ̌ o ̃ d d e e i ~ ' k a s-~}$ vattaja'. Vastaavasti puhekielen jeä'nn 'äiti' korvautuu sanalla nje'žǰ 'nisä, rinta'. Erityinen, laulettuun kieleen liittyvä sana on myös ääkkaž 'akkanen', jota käytetään maa- tai vesialueen nimeen liitettynä ja joka on samankaltainen hellittelynimi kuin suomen kielen maaemonen. Esimerkiksi: Vuõi mии šõõdd-â g-Ääkkajääur ääkkaž 'Voi minun syntymä[paikka] Akkajärvi-akkanen'.

Teksteissä on runsaasti deminutiiveja ja omistuspäätteitä. Deminutiivin tunnus on -až esimerkiksi: ââggaž 'ikänen', kuäđaž 'kotanen', šuuraž-e 'herranen', määtkaž 'matkanen', pääikaž 'paikkanen', kuâlaž, 'kalanen'. Usein nämä liittyvät erityisesti perheenjäsenten nimityksiin. Esimerkiksi sanan šõddeei 'kasvattaja' deminutiivimuoto on šõõddâž 'kasvattajainen', johon tavallisesti liittyy posses- 
siivisuffiksi šõõdd-â-žam 'kasvattajaiseni'. Vastaavasti sanaan nje'žž liittyy deminutiivimuoto njeeร̌žaž 'nisänen', johon tavallisesti liittyy possessiivisuffiksi njeeక̌žažam 'nisäseni'. (Jouste et al. 2020; vrt. Stapanova, E. 2011, 133-134.) Esimerkiksi: Pä'sseb šõõdd-â-žam Feäđat â'lğğ pä'sseb njeeว̌ž-a-žam Feäđat nijdd. 'Kiitos kasvattajaiseni Feäđatin poika, kiitos emoseni Feäđatin tyttö’.

Tyypillinen piirre on myös runsas lisätavujen ja lisävokaalien käyttö. Lauletussa koltansaamessa kuuluu usein kielihistoriallisen tavurakenteen mukaisen toisen tavun vokaali, joka on kadonnut nykypuhekielestä tai kuuluu korkeintaan niin sanottuna ylilyhyenä vokaalina, jota ei merkitä normitetussa ortografiassa sanan kirjoitusasuun. Itku- ja leu'dd-kielessä vokaali kuuluu täydessä mitassaan, ja siksi se kirjoitetaan "täysvokaalin" merkillä ja erotetaan muusta sanasta yhdysmerkillä. Pääsääntönä on, että "[p]alataalistuneen konsonantiston jälkeen tulee etuvokaali, ei-palataalistuneen konsonantiston jälkeen takavokaali" (Korhonen 1983: 147). Käytännössä tämä tarkoittaa, että toisen tavun vokaaliksi tulee a (nijdd -> nijdd-a 'tyttö, tytär', mij leä'p pü̈tt-a-maž) tai vokaali e, jos sanassa on palatalisaatio ( $\hat{a}^{\prime} \lg \check{g}$-> $\hat{a}^{\prime} \lg \check{g}$-e 'poika'). (ks. Jouste et al. 2020; Korhonen 1983: 146-147). Kaikki sanat eivät saa laulettaessa lisätavuja. Ilmiö kohdistuu laajimmin nomineihin, verbeihin ja adjektiiveihin. Pronominit ja partikkelit esiintyvät yleisimmin muuttamattomina (esim. â mat, ve't, pâi).

Lisävokaalit vaikuttavat tavujen määrään sanoissa, mutta varsinkin verbeissä esiintyy myös rakenteita, joissa verbin johdin toistetaan Ton le'žžek kuullâd-eded 'Sinä voinet kuulla-la' (Jouste et al. 2020). Sanan lopun toistorakenne esiintyy myös deminutiivien yhteydessä Ij kuâđdt-a-jam ni tuu â'lğğ-e, piârr-a-gaž-gaž-ža, 'Ei jäänyt edes sinun poikaa pikku-perheiseen-seen'. Kielihistorian kannalta nämä rakenteet eivät ole selitettävissä, mutta ne kytkeytyvät esityksen ja musiikin rakennepiirteisiin. Sekä itkuissa että leu'ddeissa on tapana hengittää usein tekstisäkeen lopussa ennen viimeistä tavua. Viimeinen tavu sidotaan seuraavaan melodiasäkeeseen siten, että sillä aloitetaan uusi rivi. Tässä yhteydessä saatetaan säerajalla toistaa sanan viimeinen tavu. Kyse on siis selkeästä ja järjestelmällisestä tyylipiirteestä.

Tekstin tyylillisistä piirteistä tärkein on parallelismi eli toisto. Toiston keinot voivat olla 1) semanttisia eli sisällön merkitykseen liittyviä, 2) syntaktisia eli lauserakenteeseen liittyviä, 3) morfologisia eli morfeemi, kuten pääte tai johdin, toistuu, 4) foneettisia eli tietty äänne toistuu ja 5) leksikaalisia eli tietty sana toistuu. 
(vrt. Stepanova, E. 2011: 133-135). Itkukielen kannalta produktiivisin toiston laji on assonanssi, jolla tarkoitetaan samojen vokaalien esiintymistä peräkkäisissä sanoissa. Kun toisto on sanojen alussa, on kyse allitteraatiosta eli alkusoinnusta. Kun toisto on sanojen lopussa, puhutaan loppusoinnusta. Tässä yhteydessä tyypillisempi on kuitenkin puolisointu eli vaillinainen loppusointu. On huomattava, että toisto ei esiinny aina täydellisenä ja eri toistorakenteiden lajeja voi esiintyä yhtä aikaa samoissa säkeissä kuten seuraavista esimerkeistä ilmenee. Selkeitä leksikaalisia paralleelirakenteita syntyy esimerkiksi silloin, kun peräkkäisissä säkeissä toistetaan samankaltaisia sanamuotoja.

Seuraavat tekstien peräkkäiset säkeet ovat semanttisesti paralleeleja. Lisäksi niissä on syntaktista, morfologista ja leksikaalista sekä foneettista toistoa.

Mâ'te tõin-e le'žžep por-a-škue'tted-ed. 'Kuten lienemme alkamaan syödä-dä.' â mat le'žžep vuei't-e-škue'tted-ed. 'Miten alkanemme jaksamaan-maan.'

Ij ve't tålǩ le'žže še vuäinn-a-maž, 'Eipä vain liene myös nähnyt,' mõõn-a le'žžep vuäinn-a-maž. 'mitä lienemme nähneet.'

Ij kuâđđt-a-jam ni tuu â'lğğ-e, piârr-a-gaž-gaž-ža, 'Ei jäänyt edes sinun poikaa pikku-perheeseen,'

ij kuâdđ-a-jam tuu nijdd-a piârr-a-gaž-ža, 'Ei jäänyt sinun tyttöä pikku-perheeseen.'

tõt kuâđđđ-a-ji, tuu nuõrr-a ââggaž jeäl-e-ǩeânna-na. 'Se jäi, sinun nuori ikäsesi, elämättä.'

jiõm-a kõõlm-a-stõõllâm-a, 'en kylmistellyt,' jiõm koolg-a-tõollâm-a. 'en kuljetellut.'

Toistorakenteita esiintyy myös yhden säkeen sisällä:

Spä'sseb-e, spä'sseb-e šuurid spä'sseb-i. 'Kiitos, kiitos, suuret kiitokset.' Â mat le'žžep jeä'l-e-škue'tted, tuu jeällež-e, 'Niin kuin lienemme alkamassa elämään, sinun elämästäsi,' Ton le'žžek kuullâd-ed-ed mâi'd-e le'žžep vuäinnam-ad. 'Sinä voinet kuulla mitä lienemme nähneet.' 
Puolisointu ilmenee seuraavassa säkeessä: Tän-a-ââ'lmest de tun-a-âlmma. 'Tästä tämänpuoleisesta ja tuonpuoleiseen.' Allitteraatio on tyylikeinona käytössä, mutta esiintyy harvakseltaan esimerkiksi säkeessä: Spä'sseb tän heä'rvv-e Helsinǩi hää'skes jie'llemsââja. 'Kiitos tästä koreasta Helsingin hauskasta asuinpaikasta.'

Kolttasaamelaisessa itkukielessä assonanssi liittyy kiinteästi lisävokaalien ja lisätavujen käyttöön. Vaikuttaakin siltä, että itkukielessä tyylitellään assonansseissa a- ja e-vokaalilla sen mukaan, kummantyyppinen lisävokaali valikoituu säkeen alkupuolella olevaan sanaan.

A-vokaali:

ij kuâdđ-a-jam tuu nijdd-a piârr-a-gaž-ža. 'Ei jäänyt sinun tyttöä pikku-perheeseen.'

tõt kuâđđđ-a-ji, tuu nuõrr-a ââggaž jeäl-e-ǩeânna-na. 'Se jäi, sinun nuori ikäsesi, elämättä.'

E-vokaali:

Â mat ve't ton-e le'žžep por-a-škue'tted-ed, â mat le'žžep vuei't-e-škue'tted-ed. 'Kuten sinä, lienemme alkamaan syödä. Kaipa lienemme alkamaan jaksaa.' Jeä'ped le'žže kuullâd-ed-ed, mâi'd-e le'žžep vuäinnam. 'Ette liene kuulleet, mitä lienemme nähneet.'

Assonasseja voidaan muodostaa myös muiden vokaalien ympärille. Seuraavassa lauseessa tämä tapahtuu õ-vokaalilla: Jiõm-a kõõlm-a-stõollâm-a, jiõm koolga-tõollâm-a. 'En kylmistellyt, en kuljetellut.'

Yleisenä huomiona voi sanoa, että mikään näistä tyylikeinoista - parallelismi, deminutiivit, omistusmuodot, metaforat - ei esiinny yksinään vaan eri keinot limittyvät jatkuvasti. Kolttasaamelaisten itkujen tekstien tyylikeinot muodostavat siis yhdessä puhekielestä poikkeavan itkukielen, jota sovelletaan jokaiseen tekstisäkeeseen. Toisaalta itkujen kieli on pitkälti rakenteeltaan ja tyylikeinoiltaan samankaltaista kuin leu'dd-kieli. 


\section{Lopuksi}

Viime vuosisadan alkupuolella osa kolttasaamelaisen musiikin perinteenlajeista on ollut luonteeltaan hyvin tilannesidonnaisia. Erityisen tilannesidonnainen on ollut itkuperinne, sillä sen rituaalinen ja yhteisöllisesti normitettu esittäminen kytkeytyi kuoleman kohtaamiseen sekä tilanteisiin, joissa ihminen joutui eroon perheestään joko avioliiton tai sotaan tai armeijaan lähtemisen vuoksi. Arkistoissa on hyvin vähän materiaalia kolttasaamelaisesta itkuperinteestä, ja pelkästään sen perusteella voidaan tarjota toistaiseksi sangen yleisluontoinen kuvaus aiheesta. Merkittävimmän työn itkuperinteen tallentamisessa teki Armas Otto Väisänen erityisesti vuoden 1926 tutkimusmatkallaan Suonikylään. Väisänen kykeni tunnistamaan ja nimeämään itkuaineistoa. Myöhemmissä keräyksissä on myös itkuja, mutta niiden tunnistamistyö on vasta aluillaan.

Olen tarkastellut itkuperinnettä aiemman tutkimuksen malliin pohjautuen ja tuonut esiin keskeisimpiä kolttasaamelaiseen itkuun liittyviä teemoja. Kuolin-, hää- ja rekryytti-itkujen lisäksi olen tulkinnut tilapääitkuiksi esityksiä, joiden erityisenä aiheena on kaipuu Suonikylän vanhoille asuinpaikoille. Itkurunojen kieli sisältää erityisiä piirteitä, kuten runsas kiittely, deminutiivien ja kiertoilmausten käyttö sekä toistorakenteet. Näille on vastineita karjalaisessa itkukielessä mutta läheisin vastaavuus löytyy kolttasaamelaisesta leu'dd-kielestä, joka on keskeinen runokieli kolttasaamelaisessa perinteessä. Eri perinteenlajien runokielen samankaltaisuuteen voi vaikuttaa se, että pienellä, enintään tuhannen puhujan kielellä, kuten kolttasaame, on lähtökohtaisesti ollut käytössä rajatumpi määrä erilaisia kontekstisidonnaisia kielen lajeja kuin esimerkiksi karjalan puhujilla, joita oli 1900-luvun alussa yli satatuhatta (Karjalainen et al. 2013: 20-26). Itkut erottuvat leu'ddista esityskontekstien ja tekstien teemojen osalta sekä musiikillisesti. Itkujen musiikillisista piirteistä huomattavaa ovat säkeiden fragmentaarisuus ja lyhyet säeaiheet.

Toisen maailmansodan jälkeinen evakko ja asuttaminen Inariin muutti kolttasaamelaisen kulttuurin elinpiiriä monin tavoin. Myös itkuvirsien esittämisen perinteiset tilanteet muuttuivat vähitellen. Tultaessa 200o-luvulle vanhojen perinteentaitajien sukupolven edustajien määrä oli enää hyvin vähäinen. Muutokset itkuperinteessä heijastavat laajemmin varsinkin 1900-luvun lopulla tapahtunutta kolttasaamelaisen suullisen perinteen ja koltansaamen kielen heikkenemistä. It- 
kuperinteen hiipumiseen liittyvät todennäköisesti myös suomalaisten hautajaisja häätapojen yleistyminen samoin kuin muutokset siinä, että nykyään surun käsittely on paljon henkilökohtaisempaa kuin ennen.

Arkistoaineistot tarjoavat yhden lisätien perinteen elvyttämiseen ja vahvistamiseen. Koska perinnettä selittävää puhetta on sangen vähän, nousee myös tallennettujen esitysten tieteellinen analyysi keskeiseen asemaan perinteen vahvistamisessa itse tallenteiden rinnalla. Arkistoaineistojen palauttaminen ja niihin liittyvän tutkimustiedon välittäminen kolttasaamelaiselle yhteisölle onkin erittäin tärkeää. Kielen vahvistamiseen ja elvytykseen on panostettu 2010-luvulla esimerkiksi Oulun yliopiston Giellagas-instituutissa ja Saamelaisalueen koulutuskeskuksessa, ja varsinkin koltansaamen kielen tilanne on saatu paranemaan. Kulttuurin osalta työtä ovat tehneet esimerkiksi Kolttakulttuurisäätiö ja Suomen Akatemian rahoittama Oulun yliopiston Kolttasaamelainen muistipankkihanke (2016-2018), jonka tavoitteena oli luoda uudenlainen aktiivinen yhteys arkistojen ja kolttasaamelaisen yhteisön välille (Jouste et al. 2018).

\section{Lähteet}

\section{Tutkimusaineisto}

Arkistoaineisto

Suomalaisen Kirjallisuuden Seuran arkisto, Perinteen ja nykykulttuurin kokoelma. Helsinki.

SKS KRA. A. O. Väisäsen kokoelma. Kotelo 6: Petsamo 1926.

SKS KRA. A 503/15-16. Näskk (Anastasia) Moshnikoff. Suonikylä 1926. Tallentaja A. O. Väisänen. SKS KRA. L 277a. Näskk (Anastasia) Moshnikoff. Helsinki 1936. Tallentaja A. O. Väisänen.

Kansanperinteen arkisto, Yhteiskunta- ja kulttuuritieteiden yksikkö, Tampereen yliopisto. Tampere.

Kper AK/0548. Dä'rjj (Darja) Jefremoff. Sevettijärvi 1961. Tallentaja Erkki Ala-Könni. 
Kper AK/0561. U'lljan (Uljaana) Fofanoff. Sevettijärvi 1961. Tallentaja Erkki Ala-Könni.

Kper AK/0864. Dä'rjj (Darja) Jefremoff. Helsinki 1955. Tallentaja Erkki Ala-Könni.

Kper AK/0871. Dä'rjj (Darja) Jefremoff. Helsinki 1955. Tallentaja Erkki Ala-Könni.

Suomen kielen nauhoitearkisto. Kotimaisten kielten keskus. Helsinki.

SKNA 09839a. Ååjjaž (Oijaš) Fofanoff. Sevettijärvi 1971. Tallentaja Mikko Korhonen.

\section{Haastattelut}

Lati Feodoroff (h2020). 16.10.2020. Kolttasaamelaista itkua käsittelevä puhelinkeskustelu, joka liittyy aiempaan kolttasaamelaisen yhteisön kanssa käytyyn yleisökeskusteluun Marko Jousteen esitelmän "Evakkoaiheita leu'dd-perinteessä" yhteydessä Vâčc pihttsid kââčc - Viima kysyy vaatteita -seminaarissa Nellimissä 12.12.2019. Muistiinpanot kirjoittajan hallussa.

\section{Tutkimuskirjallisuus}

Asplund, Anneli (2006) "Itkuvirsi". Suomen musiikin historia. Kansanmusiikki. Toim. Päivi Kerola-Innala, Leena Lönnroth, Katrti Maasalo, Eliisa Valkama \& Ralf Wessman. Helsinki: WSOY, 80-104.

Honko, Lauri (1963) 'Itkuvirsirunous". Suomen Kirjallisuus 1. Kirjoittamaton kirjallisuus. Toim. Matti Kuusi. Helsinki: Suomalaisen Kirjallisuuden Seura ja Kustannusosakeyhtiö Otava, 81-128.

Honko, Lauri (1974) "Balto-Finnic Lament Poetry". Finnish Folkloristics I. Toim. Pentti Leino yhteistyössä Annikki Kaivola-Bregenhøj’n ja Urpo Venton kanssa. Studia Fennica XVII. Helsinki: Suomalaisen Kirjallisuuden Seura, 9-61.

Häkämies, Irja (1978) "Kolttasaamelainen musiikkiperinne". Kansanmusiikki 2/1978. Kaustinen: Kansanmusiikki-instituutti, 16-19.

Hämäläinen, Antti (1938) Koltta-Lappia sanoin ja kuvin. Uutta Lapin lääniä I. Helsinki: WSOY. Itkonen, Toivo Ilmari (1948) Suomen lappalaiset vuoteen 1945. I-II. Porvoo: WSOY. Itkonen, Toivo Ilmari (1958) Koltan- ja Kuolanlapin sanakirja. Lexica Societatis Fenno-Ugricae XV. Helsinki: Suomalais-Ugrilainen Seura.

Jouste, Marko (2006) "Suomen saamelaisten musiikkiperinteet". Suomen musiikin historia. Kansanmusiikki. Toim. Päivi Kerola-Innala, Leena Lönnroth, Katrti Maasalo, Eliisa Valkama \& Ralf Wessman. Helsinki: WSOY, 272-307. 
Jouste, Marko (2008) "Venäläisen bylinan ja kolttasaamelaisen leuddin välisestä yhteydestä”. Musiikin suunta 2008/3-4. Helsinki: Suomen Etnomusikologinen Seura, 11-31.

Jouste, Marko (2011) "Katsaus koltan- ja kuolansaamelaisiin musiikkiperinteisiin". Sommelon säikeitä. Runolaulu-Akatemian seminaarijulkaisu 2009-2010. Toim. Pekka Huttu-Hiltunen, Janne Seppänen, Frog, Eila Stepanova \& Riikka Nevalainen. Juminkeon julkaisuja nro 86. Kuhmo: Juminkeko, 51-74. Jouste, Marko (2014) "Katsaus Venäjän saamelaisten musiikkiperinteiden keräykseen ja tutkimukseen". Song and Emergent Poetics Oral Traditions in Performance: Conference Proceedings, 21st-24th November 2013. Toim. Pekka Huttu-Hiltunen, Frog, Karina Lukin, Sari Karikko \& Eila Stepanova. Runolaulu-Akatemian julkaisuja 18. Kuhmo: Runolaulu-Akatemia, Juminkeko, 189-222.

Jouste, Marko (2017) "The Historical Skolt Saami Music and Two Types of Melodic Structures in Leu'dd Tradition”. Folklore 67. Tartu: Estonian Literary Museum, 69-84. https://doi.org/10.7592/FEJF2017.68.jouste.

Jouste, Marko (2019) "New Study on Skolt Saami Laments". The Retrospective Methods Network Newsletter 2019. Helsinki: University of Helsinki, 151-153.

Jouste, Marko; Juutinen, Markus \& Koponen, Eino (2020) [painossa] "Kolttasaamelaisen Näskk Moshnikoffin leu'dd-kielen idiolekti”. Kulttuurintutkimus 1-2/2020, 32-56.

Jouste, Marko; Juutinen, Markus; Lehtinen, Miika; Lumikivi, Anna \& Kiprianoff, Hanna-Maaria (2018) "Sää'mǩiõl da kulttuur jeälltummuš Skolt Saami Memory Bank-ha'y̌̌ǩ̃õõzzâst". Dutkansearvvi dieđalaš áige čála 2:1, 24-29. http://dutkansearvi.fi/volume-2-issue-1-en/

Jouste, Marko; Mosnikoff, Elias \& Sivertsen, Seija (2007) Maaddârääjji leeu'd - Historiallisia kolttasaamelaisia leu'ddeja. Inari, Kaustinen: Saamelaimuseo Siida \& Kansanmusiikki-Instituutti \& Kolttien kyläkokous.

Karjalainen, Heini; Puura, Ulriikka; Grünthal, Riho \& Kovaleva, Svetlana (2013) "Karelian in Russia. ELDIA Case Specific Report." http://phaidra.univie.ac.at/o:314612 [viitattu 20.10.2020].

Karjalan kielen sanakirjan hakusanaluettelo [online-tietokanta, Päivitetty 28.2.2020]. Helsinki: Kotimaisten kielten keskus. Hakusana: 'tuonilmaine' [viitattu 22.9.2020]. (Sisältyy kokoelmaan Sukukielet) Saatavissa: http://kaino.kotus.fi/sanat/kkss/

Konkka, Unelma (1985) Ikuinen ikävä. Suomalaisen Kirjallisuuden Seuran Toimituksia 428. Helsinki: Suomalaisen Kirjallisuuden Seura.

Korhonen, Mikko (1983) "Kolttalaulujen fonologiaa". Suomalais-Ugrilaisen Seuran Aikakausikirja nro. 78. Helsinki: Suomalais-Ugrilainen seura, 133-152.

Laitinen, Heikki (1977) Suonikylän laulut vuonna 1961. Tutkielma kolttasaamelaisten musiikkiperinteestä. Pro gradu -tutkielma. Helsinki: Helsingin yliopisto, Musiikkitieteen laitos. 
Laitinen, Heikki (1981) "Saamelaisten musiikki". Kansanmusiikki. Toim. Anneli Asplund \& Matti Hako. Suomalaisen Kirjallisuuden Seuran toimituksia 366. Helsinki: Suomalaisen Kirjallisuuden Seura, 179-198.

Launis, Armas (1922) Kaipaukseni maa: Lapinkävijän matkamuistoja. Jyväskylä: Gummerus.

Lehtola, Veli-Pekka (2015) Saamelaiset - Historia, yhteiskunta, taide. Inari: Kustannus-Puntsi.

Leisiö, Timo (1978) "Saamelaisten vanhakantainen musiikkikulttuuri”. Kansanmusiikki 2/1978.

Kaustinen: Kansanmusiikki-instituutti, 2-15.

Linkola, Anni \& Linkola, Martti (2000) "Kolttasaamelaiset - vähemmistön vähemmistö". Siiddastalla.

Siidoista kyliin. Luontosidonnainen saamelaiskulttuuri ja sen muuttuminen. Toim. Jukka Pennanen ja

Klemetti Näkkäläjärvi. Inarin saamelaismuseon julkaisuja nro 3. Jyväskylä: Pohjoinen, 158-167.

Linkola, Martti (1985). ”Jaakko Sverloff”. Lappi 4. Hämeenlinna: Arvi A. Karisto Oy, 99.

Mustonen, Tero \& Mustonen, Kaisu (2011) Eastern Sámi Atlas. Vaasa: Snowchange cooperative.

Niemi, Jarkko \& Jouste, Marko 2013. "Musiikin paradigmaattinen analyysi”. Musiikki kulttuurina. Toim.

Pirkko Moisala \& Elina Seye. Suomen Etnomusikologisen Seuran julkaisuja 21. Helsinki: Suomen Etnomusikologinen Seura, 173-200.

Saastamoinen, Ilpo (2000) 'Itäsaamelaisten musiikkiperinteestä". Beaivvi mánát. Saamelaisten juuret ja nykyaika. Tietolipas 164. Toimittanut Irja Seurujärvi-Kari. Helsinki: Suomalaisen Kirjallisuuden Seura, 83-122.

Silvonen, Viliina \& Stepanova, Eila (2019) "Language, Music and Emotion in Lament Poetry: The Embodiment and Performativity of Emotions in Karelian Laments". The Routledge Handbook of Language and Emotion. Toim. S. E. Pritzker, J. Fenigsen, \& J. M. Wilce. London: Routledge, 203222. https://doi.org/10.4324/9780367855093-12

Stepanova, Aleksandra (2012) Karjalaisen itkuvirsikielen sanakirja. Suomalaisen Kirjallisuuden Seuran toimituksia 1366. Helsinki: Suomalaisen Kirjallisuuden Seura.

Stepanova, Eila (2009) "Itkukielen metaforat ja itkujen dramaturgia". Kantele, runolaulu ja itkuvirsi. Runolauluakatemian seminaarijulkaisu. Toim. Pekka Huttu-Hiltunen, Frog, Janne Seppänen \& Eila Stepanova. Kuhmo: Juminkeko, 13-25.

Stepanova, Eila (2011) "Reflections of Belief Systems in Karelian and Lithuanian Laments: Shared Systems of Traditional Referentiality?" Archaeologia Baltica 15. Toim. Daiva Vaitkevičienė \& Vykintas Vaitkevičius. Klaipėda: Klaipėda University Press, 128-143.

https://doi.org/10.15181/ab.v15i1.18

Stepanova, Eila (2015) "The Register of Karelian Lamenters". Registers of Communication. Toim. Asif

Agha \& Frog. Studia Fennica Linguistica 18. Helsinki: Suomalaisen Kirjallisuuden Seura, 258-274. https://doi.org/10.2307/j.ctvggx2qk.18 
Storå, Nils (1971) Burial customs of the Skolt Lapps. FF communications, no. 210. Helsinki: Suomalainen tiedeakatemia - Academia scientiarum Fennica.

Tolvanen, Viliina (2014) Ikäväistä itkua, vilua virttä. Itkun rakenne ja merkityksen muodostuminen tekstin, sävelmän ja tunteen vuorovaikutuksesta aunuslaisissa itkuvirsissä. Pro gradu -tutkielma. Turku: Turun yliopisto, Historian, kulttuurin ja taiteiden tutkimuksen laitos. 